\title{
Water Quality in the Surficial Aquifer Near Agricultural Areas in the Delaware Coastal Plain, 2014
}

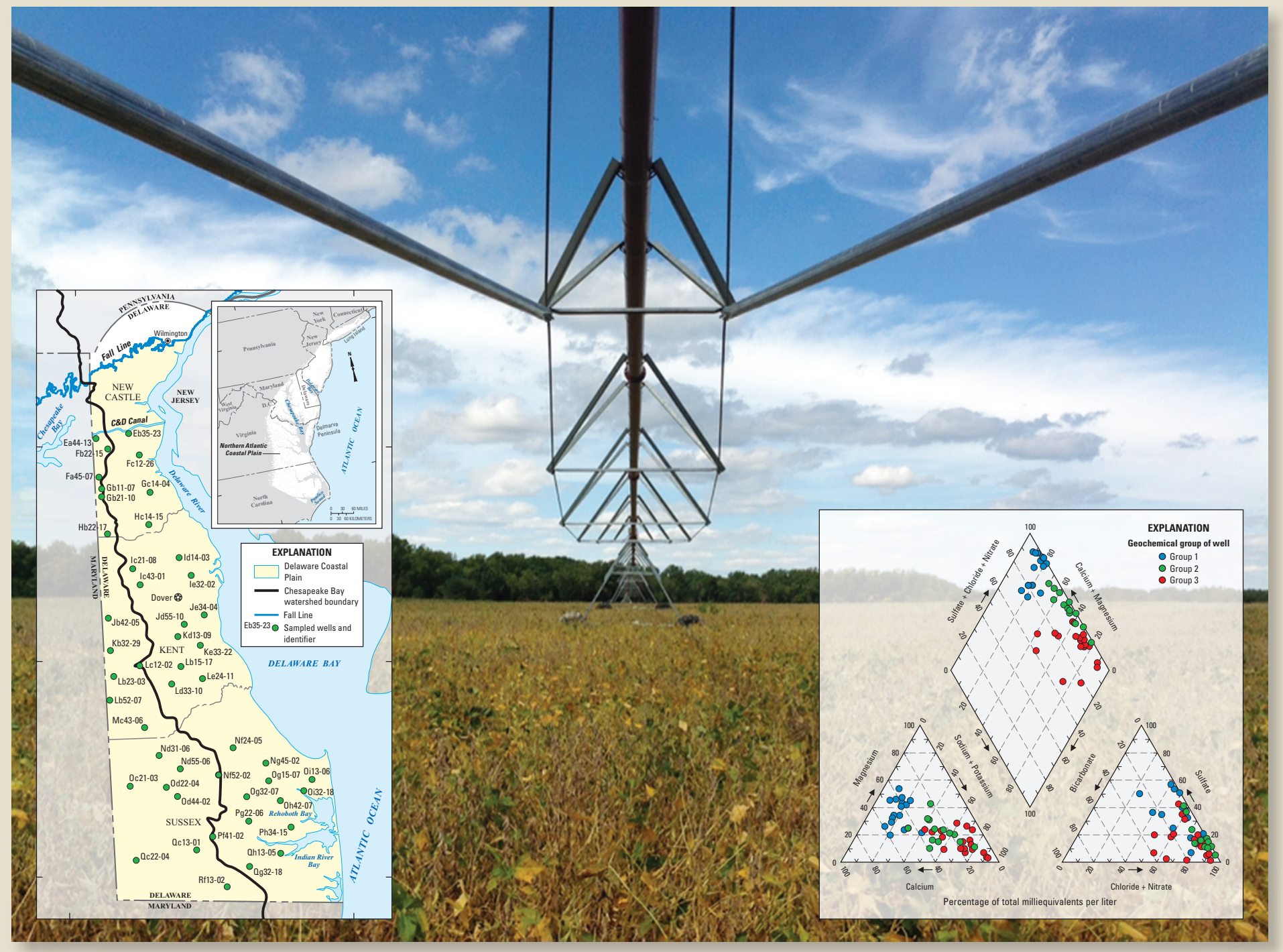

Scientific Investigations Report 2017-5054 
Cover. Map showing the Delaware Coastal Plain and location of wells (refer to figure 1); trilinear diagram of major ions within the surficial aquifer of the Delaware Coastal Plain by geochemical groups (refer to figure 6); and center-pivot irrigation system over soybean field. Photograph by John W. Clune, U.S. Geological Survey. 


\section{Water Quality in the Surficial Aquifer Near Agricultural Areas in the Delaware Coastal Plain}

By Brandon J. Fleming, Laura L. Mensch, Judith M. Denver, Roberto M. Cruz, and Mark R. Nardi

Prepared in cooperation with the Delaware Department of Agriculture

Scientific Investigations Report 2017-5054 


\title{
U.S. Department of the Interior \\ RYAN K. ZINKE, Secretary
}

\section{U.S. Geological Survey William H. Werkheiser, Acting Director}

\author{
U.S. Geological Survey, Reston, Virginia: 2017
}

For more information on the USGS - the Federal source for science about the Earth, its natural and living resources, natural hazards, and the environment, visit https://www.usgs.gov or call 1-888-ASK-USGS

For an overview of USGS information products, including maps, imagery, and publications, visit https://store.usgs.gov

Any use of trade, product, or firm names is for descriptive purposes only and does not imply endorsement by the U.S. Government.

Although this report is in the public domain, permission must be secured from the individual copyright owners to reproduce any copyrighted materials contained within this report.

Suggested citation:

Fleming, B.J., Mensch, L.L., Denver, J.M., Cruz, R.M., and Nardi, M.R., 2017, Water quality in the surficial aquifer near agricultural areas in the Delaware Coastal Plain, 2014: U.S. Geological Survey Scientific Investigations Report 2017-5054, 28 p., https://doi.org/10.3133/sir20175054.

ISSN 2328-0328 (online) 


\section{Acknowledgments}

The authors wish to extend special thanks to Ed Kee, formerly of the Delaware Department of Agriculture (DDA), for initiating and supporting this study. Thanks to Jessica Teunis of the U.S. Geological Survey (USGS) and Luke Myers, formerly of the USGS, for collecting much of the data for this report. The authors appreciate the technical reviews by Scott Ator of the USGS and Joshua Kasper of the Delaware Department of Natural Resources and Environmental Control (DNREC). 



\section{Contents}

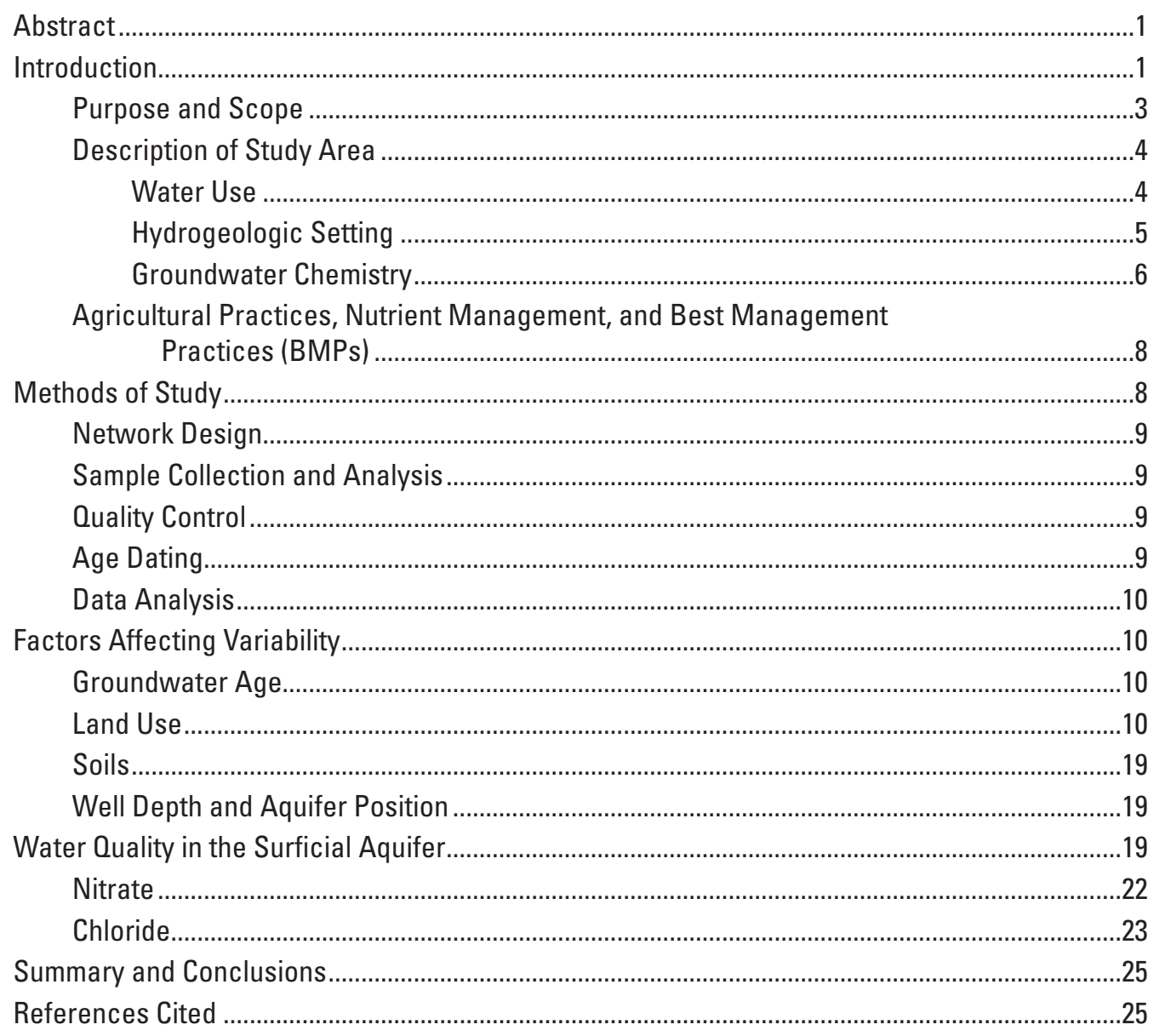




\section{Figures}

1. Map showing the Delaware Coastal Plain and location of wells .....................................2

2. Pie chart showing nitrogen inputs to Delaware...............................................................

3. Pie chart showing groundwater use by $A$, category for the Delaware Coastal Plain, 2010, and $B$, scatter plot showing acres irrigated and volume withdrawn for agricultural irrigation in the Delaware Coastal Plain .....................

4. Map showing the thickness of the surficial aquifer in the Delaware Coastal Plain.

5. Results of correlation and cluster analysis, $A$, dendrogram showing the grouping of wells by correlation and cluster analysis, and $B$, map showing the spatial distribution of geochemical groups.

6. Trilinear diagram of major ions within the surficial aquifer of the Delaware Coastal Plain by geochemical groups

7. Boxplots of $A$, nitrate, $B$, calcium, and $C$, magnesium concentrations by geochemical groups

8. Boxplots of $A$, agricultural land use, and $B$, developed land use by geochemical groups.

9. Boxplots of $A$, chloride, $B$, chloride to bromide ratio by geochemical groups, and $C$, scatter plot of chloride to bromide ratio compared to chloride by latitude.

\section{Tables}

1. Site information for wells sampled in the surficial aquifer of the Delaware Coastal Plain, 2014

2. Water characteristics, major ion, nutrient, and atmospheric age tracer results from groundwater in the surficial aquifer of the Delaware Coastal Plain, 2014

3. Summary statistics for selected physical properties and major ions and elements of groundwater in the surficial aquifer of the Delaware Coastal Plain, 2014 


\section{Conversion Factors}

\begin{tabular}{|c|c|c|}
\hline Multiply & By & To obtain \\
\hline \multicolumn{3}{|c|}{ Length } \\
\hline inch (in) & 2.54 & centimeter $(\mathrm{cm})$ \\
\hline foot $(\mathrm{ft})$ & 0.3048 & meter $(\mathrm{m})$ \\
\hline mile (mi) & 1.609 & kilometer $(\mathrm{km})$ \\
\hline \multicolumn{3}{|c|}{ Area } \\
\hline acre & 0.4047 & hectare (ha) \\
\hline acre & 0.004047 & square kilometer $\left(\mathrm{km}^{2}\right)$ \\
\hline square mile $\left(\mathrm{mi}^{2}\right)$ & 259.0 & hectare (ha) \\
\hline square mile $\left(\mathrm{mi}^{2}\right)$ & 2.590 & square kilometer $\left(\mathrm{km}^{2}\right)$ \\
\hline \multicolumn{3}{|c|}{ Volume } \\
\hline gallon (gal) & 3.785 & liter $(\mathrm{L})$ \\
\hline \multicolumn{3}{|c|}{ Flow rate } \\
\hline million gallons per day (Mgal/d) & 0.04381 & cubic meter per second $\left(\mathrm{m}^{3} / \mathrm{s}\right)$ \\
\hline inch per year (in/yr) & 25.4 & millimeter per year (mm/yr) \\
\hline \multicolumn{3}{|c|}{ Mass } \\
\hline ounce, avoirdupois (oz) & 28.35 & gram $(\mathrm{g})$ \\
\hline pound, avoirdupois (lb) & 0.4536 & kilogram (kg) \\
\hline
\end{tabular}

Temperature in degrees Celsius $\left({ }^{\circ} \mathrm{C}\right)$ may be converted to degrees Fahrenheit $\left({ }^{\circ} \mathrm{F}\right)$ as follows:

$$
{ }^{\circ} \mathrm{F}=\left(1.8 \times{ }^{\circ} \mathrm{C}\right)+32
$$

\section{Datums}

Vertical coordinate information is referenced to the National Geodetic Vertical Datum of 1988 (NGVD 88).

Horizontal coordinate information is referenced to North American Datum of 1983 (NAD 83).

Altitude, as used in this report, refers to distance above the vertical datum.

\section{Supplemental Information}

Specific conductance is given in microsiemens per centimeter at 25 degrees Celsius $\left(\mu \mathrm{S} / \mathrm{cm}\right.$ at $\left.25^{\circ} \mathrm{C}\right)$.

Concentrations of chemical constituents in water are given in either milligrams per liter (mg/L) or micrograms per liter $(\mu \mathrm{g} / \mathrm{L})$. 


\section{Abbreviations}

DDA Delaware Department of Agriculture

DGS Delaware Geological Survey

DNREC Delaware Department of Natural Resources and Environmental Control

EPA U.S. Environmental Protection Agency

NASS National Agricultural Statistics Service

NRCS Natural Resources Conservation Service

NWQL National Water Quality Laboratory

NWIS National Water Information System

TMDL Total Maximum Daily Load

USDA U.S. Department of Agriculture

USGS U.S. Geological Survey 


\title{
Water Quality in the Surficial Aquifer Near Agricultural Areas in the Delaware Coastal Plain, 2014
}

\author{
By Brandon J. Fleming', Laura L. Mensch², Judith M. Denver', Roberto M. Cruz', and Mark R. Nardi'
}

\begin{abstract}
The U.S. Geological Survey, in cooperation with the Delaware Department of Agriculture, developed a network of wells to monitor groundwater quality in the surficial aquifer of the Delaware Coastal Plain. Well-drained soils, a flat landscape, and accessible water in the Delaware Coastal Plain make for a productive agricultural setting. As such, agriculture is one of the largest industries in the State of Delaware. This setting enables the transport of chemicals from agriculture and other land uses to shallow groundwater. Efforts to mitigate nutrient transport to groundwater by the implementation of agricultural best management practices (BMPs) have been ongoing for several decades. To measure the effectiveness of BMPs on a regional scale, a network of 48 wells was designed to measure shallow groundwater quality (particularly nitrate) over time near agricultural land in the Delaware Coastal Plain. Water characteristics, major ions, nutrients, and dissolved gases were measured in groundwater samples collected from network wells during fall 2014. Wells were organized into three groups based on their geochemical similarity and these groups were used to describe nitrate and chloride concentrations and factors that affect the variability among the groups. The results from this study are intended to establish waterquality conditions in 2014 to enable comparison of future conditions and evaluate the effectiveness of agricultural BMPs on a regional scale.
\end{abstract}

\section{Introduction}

More than 90 percent of Delaware is underlain by the Northern Atlantic Coastal Plain Aquifer system (fig. 1). Most of the Delaware Coastal Plain has a surficial aquifer with a shallow water table and is typically composed of sandy sediments. Abundant rainfall provides aquifer recharge, but can also carry chemicals from the land surface to the water table.

\footnotetext{
${ }^{1}$ U.S. Geological Survey.

${ }^{2}$ Delaware Department of Agriculture.
}

This aquifer is an important source of drinking water for many residents of small towns and rural households with domestic use. The surficial aquifer also provides most of the streamflow for streams that originate in the Delaware part of the Coastal Plain.

As plants grow, they extract nutrients from the soil. In order to maintain crop yields and plant health, farmers need to periodically replace these nutrients by adding either animal manure or commercial fertilizers to the soil. Most nitrogen is applied to the land in the form of organic nitrogen or ammonia in manures and commercial fertilizers. Much of the applied nitrogen is rapidly converted to nitrate by soil microbes. Nitrate dissolves in water and the amounts not used by crops can leach into the groundwater with recharge. Certain conditions increase the likelihood of nitrate moving into shallow groundwater. These conditions include the amounts and timing of nitrogen application to the land; the presence of well-drained, sandy soils that promote oxic soil and aquifer conditions (dissolved oxygen greater than 1 milligram per liter or $\mathrm{mg} / \mathrm{L}$ ); and a relatively high water table (Ator and Denver, 2015; Rudolph, 2015). These conditions are common in many parts of the Delaware Coastal Plain and have resulted in widespread nitrate movement into the surficial aquifer in many areas.

Nitrate, the major form of nitrogen that is soluble in water, is a common contaminant in groundwater and surface water in the Coastal Plain of Delaware (Ator and Denver, 2015). Nitrate concentrations in the surficial aquifer are commonly far greater than would be expected under natural conditions, and often high enough to affect the suitability of water for human consumption (Debrewer and others, 2007). Nitrate from groundwater is the primary source of nitrogen to many streams, which often exceed the U.S. Environmental Protection Agency (EPA) Total Maximum Daily Load (TMDL) for surface-water quality (Delaware Department of National Resources and Environmental Control, 2015). Manure and fertilizer used for agriculture are the primary sources of nitrogen applied to the land in Delaware (fig. 2). The recognition of this water-quality concern has led to the implementation of agricultural nutrient management efforts designed to maximize yields while minimizing any potentially negative effects on environmental quality. 


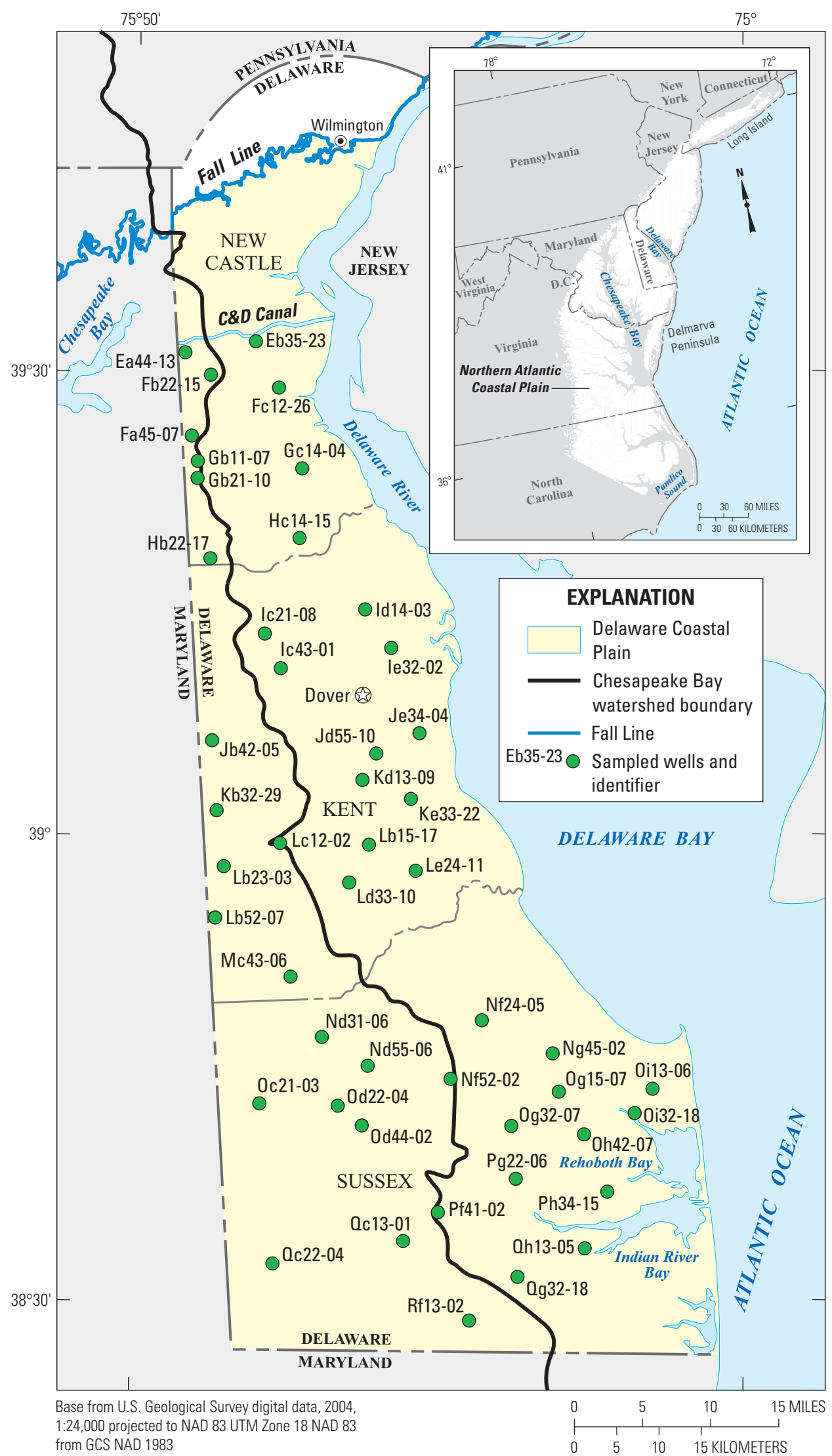

Figure 1. The Delaware Coastal Plain and location of wells. 


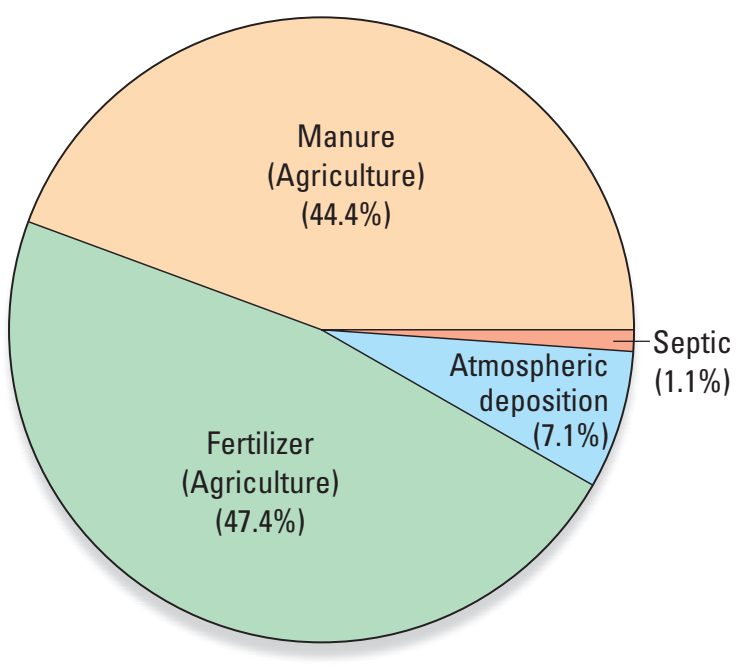

EXPLANATION

Fertilizer applications or (for nitrogen) direct fixation from the atmosphere by crops (Brakebill and Gronberg, 2017).

Manure (Gronberg and Arnold, 2017).

Atmospheric deposition (National Atmospheric Deposition Program, 2015).

Septic (Estimated using method developed by Maizel and others, 1997).

Figure 2. Nitrogen inputs to Delaware. (\%, percent)

Agriculture is one of Delaware's main industries, producing over $\$ 1$ billion in annual sales. With 508,000 total acres of farmland in the State, roughly 2 out of every 5 acres in Delaware are dedicated to farming. Delaware's average farm size of 200 acres is less than half the national average farm size of 438 acres, reflecting the prevalence of smaller farms. Poultry, predominantly broiler chickens, is one of the largest agricultural commodities in the State. The largest amount of farmland in the State is planted with the main crops: soybeans, corn, and wheat, with 415,000 total acres of these three crops combined (U.S. Department of Agriculture, National Agricultural Statistics Service, 2012). Produce, such as watermelons, sweet corn, lima beans, and cucumbers, also accounts for a part of the State's agricultural production.

Between 2005 and 2013, an annual average of 110,053 tons of poultry manure was applied to 49,268 acres of Delaware farmland (Delaware Department of Agriculture, 2015). That is an average of 2.23 tons of poultry manure applied per acre. Since poultry manure is composed of approximately 3 percent nitrogen (Delaware Department of Agriculture, 2012), farmers applied an annual average of 133 pounds of nitrogen per acre from poultry litter. Another major source of soil amendments used in the State is commercial fertilizer. In 2013, Delaware farmers reported applying 9,632 tons of nitrogen from commercial fertilizer on
194,898 acres of Delaware farmland (Delaware Department of Agriculture, 2015). That is an average of 99 pounds of nitrogen per acre from commercial fertilizer (U.S. Department of Agriculture, 2012). Combined, an average of about 232 pounds of nitrogen per acre annually are applied to farmland in Delaware.

Under State law (Delaware Code Title 3), every farm that applies nutrients to 10 or more acres must have a valid Nutrient Management Plan written by a Delaware certified nutrient consultant. Application of manure from poultry production is included in many Nutrient Management Plans for Delaware farms because of the value of manure as a nutrient source and its abundance. A fundamental goal of any nutrient management plan is to identify the most cost-efficient and environmentally sound way to provide plants with the optimum supply of nutrients. Success with conservation and nutrient application practices used in these plans should help to reduce concentrations of nitrate over time in Delaware waters.

A groundwater-monitoring network was established in 2014 by the U.S. Geological Survey (USGS) and the Delaware Department of Agriculture (DDA) as a tool to measure changes in water quality over time in the Delaware Coastal Plain. Temporal trends in nitrate have been evaluated in groundwater networks in different hydrogeologic settings, including the Columbia Basin in Washington (Frans and Helsel, 2005), and the California Central Valley (Burow and others, 2012). In the Mid-Atlantic region, temporal trends in nitrate and pesticides were evaluated in the Valley and Ridge carbonate aquifers and the Delmarva Peninsula (Debrewer and others, 2008). Networks in similar hydrogeologic and land-use settings in Denmark (Hansen and others, 2011) have shown improvements in groundwater quality with changes in agricultural practices. Initial data from the network established by USGS and DDA demonstrated groundwater-quality conditions near agricultural lands in the Delaware Coastal Plain in 2014. Repeated sampling of this network over time is intended to help track the effectiveness of agricultural best management practices (BMPs) aimed at reducing nitrogen transport to the water table in Delaware.

\section{Purpose and Scope}

The purposes of this report are to describe the design of an agricultural, shallow groundwater-quality monitoring network in the Delaware Coastal Plain and to present geochemical results of samples collected from the network in 2014. This study focuses on the 2014 water-quality conditions in shallow groundwater near agriculture, which is the predominant land use in Delaware. Results presented in this report are based on the analyses of samples collected at 48 shallow wells (fig. 1, table 1) in or adjacent to agricultural lands that are distributed throughout the Delaware Coastal Plain. These data allow comparison with future samples collected for a study of trends in nitrate and other chemicals in groundwater in the Delaware Coastal Plain. 
Table 1. Site information for wells sampled in the surficial aquifer of the Delaware Coastal Plain, 2014.

[DNREC, Delaware Department of Natural Resources and Environmental Control; ft bls, feet below land surface; ft, feet]

\begin{tabular}{|c|c|c|c|c|c|c|}
\hline Station number & $\begin{array}{c}\text { Local } \\
\text { identifier }\end{array}$ & $\begin{array}{c}\text { DNREC } \\
\text { well identifier }\end{array}$ & $\begin{array}{c}\text { Latitude } \\
\text { (decimal degrees) }\end{array}$ & $\begin{array}{c}\text { Longitude } \\
\text { (decimal degrees) }\end{array}$ & $\begin{array}{c}\text { Well depth } \\
\text { (ft bls) }\end{array}$ & $\begin{array}{c}\text { Aquifer thickness } \\
\text { (ft) }\end{array}$ \\
\hline 392959075435501 & $\mathrm{Fb} 22-15$ & 106879 & 39.499834 & -75.731599 & 23.34 & 67 \\
\hline 382932075221701 & Rf13-02 & 155971 & 38.492083 & -75.371417 & 12.9 & 19 \\
\hline 384425075072401 & Oi13-06 & 166167 & 38.740167 & -75.123444 & 13 & 95 \\
\hline 391324075391901 & Ic21-08 & 172352 & 39.223444 & -75.655222 & 17.3 & 25 \\
\hline 385956075303801 & Lb15-17 & 172301 & 38.999 & -75.510583 & 13.1 & 62 \\
\hline 391814075435001 & Hb22-17 & 172331 & 39.303889 & -75.730472 & 12.3 & 41 \\
\hline 392403075362101 & Gc14-04 & 187638 & 39.4009 & -75.605817 & 34 & 23 \\
\hline 390634075433401 & $\mathrm{Jb} 42-05$ & 172323 & 39.109444 & -75.726194 & 11.1 & 11 \\
\hline 391503075310401 & Id14-03 & 155985 & 39.250917 & -75.517722 & 18 & 15 \\
\hline 384637075153201 & $\mathrm{Ng} 45-02$ & 187640 & 38.777067 & -75.258867 & 22 & 114 \\
\hline 392324075445601 & $\mathrm{~Gb} 21-10$ & 106885 & 39.390111 & -75.748544 & 14.75 & 61 \\
\hline 383438075274201 & Qc13-01 & 155972 & 38.577167 & -75.46175 & 13.1 & 128 \\
\hline 383221075182301 & Qg32-18 & 166165 & 38.539222 & -75.306472 & 11.8 & 19 \\
\hline 384316075330501 & Od22-04 & 155961 & 38.721 & -75.551333 & 18.3 & 76 \\
\hline 384201075185401 & Og32-07 & 166198 & 38.700222 & -75.315028 & 13.2 & 104 \\
\hline 385830075423201 & Lb23-03 & 172347 & 38.975 & -75.708944 & 13.2 & 50 \\
\hline
\end{tabular}

\section{Description of Study Area}

Most of Delaware lies on the Delmarva Peninsula within the Northern Atlantic Coastal Plain Physiographic Province (fig. 1). Topography in the Delaware Coastal Plain is relatively flat with the highest elevations located at the drainage divide between the Chesapeake Bay to the west and Delaware Bay and Atlantic Ocean to the east (fig. 1). On the Delaware Coastal Plain, land use is predominantly agriculture, forest and wetlands, and developed at 53 percent, 39 percent, and 8 percent, respectively (Masterson and others, 2016). Average annual precipitation ranges from 41 to 45 inches per year (in/yr) (Sanford and others, 2012) and is typically evenly distributed throughout the year with 3-4 inches per month.

\section{Water Use}

Total 2010 groundwater use in the Delaware Coastal Plain was 151 million gallons per day (Mgal/d), of which most (58 percent) was used for agriculture (Masterson and others, 2016; fig. 3A). Over the last several decades, both irrigated land (U.S. Department of Agriculture, National Agricultural Statistics Service, 2012) and the volume of groundwater withdrawn for irrigation has increased substantially (Cheryl Dieter, USGS, written commun., 2016; fig. 3B). Most public water supply and all domestic water use in the Delaware Coastal Plain comes from confined aquifers or relatively thick parts of the surficial aquifer. Other uses of groundwater include commercial and industrial use. 
Table 1. Site information for wells sampled in the surficial aquifer of the Delaware Coastal Plain, 2014._Continued

[DNREC, Delaware Department of Natural Resources and Environmental Control; ft bls, feet below land surface; ft, feet]

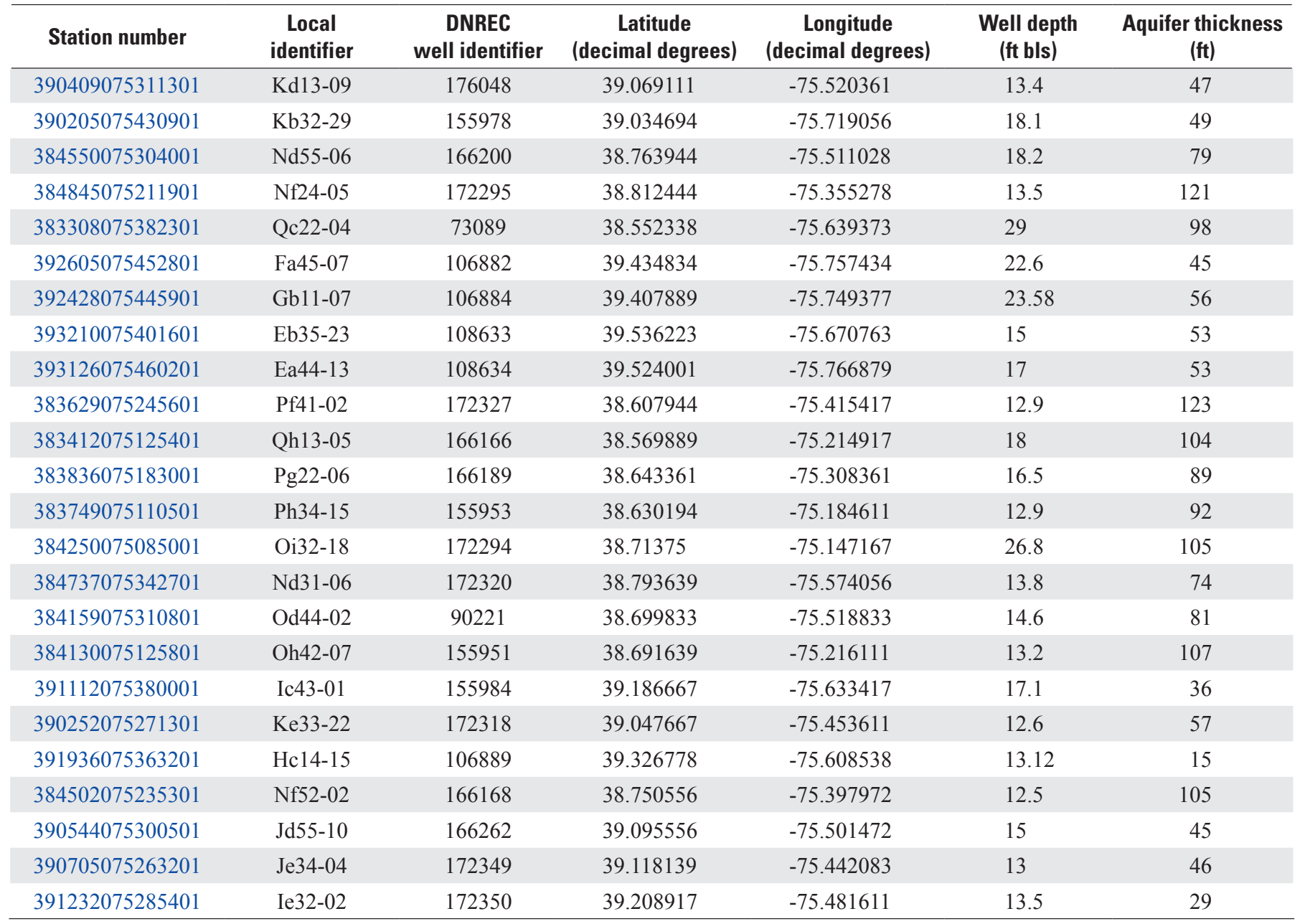

\section{Hydrogeologic Setting}

The Delaware Coastal Plain is underlain by an extensive unconfined surficial aquifer that is present at the land surface in most areas (fig. 4). This aquifer supplies most of the flow to streams and rivers that incise the land surface. It generally thickens from north to south (fig. 4) and overlies the subcrop areas of a series of confined aquifers and confining beds (Denver and Nardi, 2016).

The recharge area for the surficial aquifer includes most of the land surface because of the sandy nature of the aquifer sediments. The mean annual estimated recharge ranges from about 14 to $17 \mathrm{in} / \mathrm{yr}$, which is about one-third of the total precipitation (Sanford and others, 2012). Water in the surficial aquifer typically flows along relatively short flow paths (distances of several hundred feet to less than a few miles) towards discharge areas in streams and estuaries and reaches the discharge areas in less than 50 years (Denver and others, 2004; Sanford and others, 2012). Groundwater flow is also intercepted by pumping wells. A small amount of the recharge, less than 2 percent, moves downward into the underlying confined aquifers (Leahy and Martin, 1993).

Geologic formations with predominantly sandy surficial sediments that compose the surficial aquifer in the Delaware Coastal Plain include the Parsonsburg Sand, Sinepuxent Formation (Fm.), and parts of the Omar Fm., the Columbia Fm., the Beaverdam Fm., and the Pennsauken Fm. (Ator and others 2005; Bachman and Wilson, 1984). Other formations 
with mixed texture that have sandy lithology also can be part of the surficial aquifer. These formations include the Scotts Corner Fm. and Lynch Heights Fm., which occur on the eastern side and updip section of the Omar Fm. north of Indian River Bay (Ator and others, 2005; Mixon, 1985; Owens and Denny, 1979; Ramsey, 1997). These formations are of Quaternary through late Miocene age.

Aquifers that are otherwise confined that underlie the surficial aquifer may increase its thickness in areas where they subcrop beneath the surficial aquifer and are under water-table conditions. Older formations that contain aquifers and subcrop the surficial aquifer include the Tertiary age formations of the Chesapeake Group, and the Vincentown and Hornerstown Fms.; the Cretaceous age Mt. Laurel, Englishtown, and Magothy Fms., and the sandy sediments of the Potomac Group (Ator and others, 2005).

\section{Groundwater Chemistry}

The chemical constituents measured in groundwater reflect the rock types of the aquifer sediments, redox conditions in the aquifer, and chemicals applied to the land surface that are soluble in water and available to leach into the groundwater system. The surficial aquifer in the Delaware Coastal Plain is composed mostly of siliciclastic sediments in which quartz minerals are the major component (Jordan, 1964). Quartz is resistant to weathering, and under natural conditions in well-drained areas with minimal inputs of anthropogenic chemicals, the water in the surficial aquifer system is very dilute with specific conductance of less than about 60 microsiemens per centimeter at 25 degrees Celsius $(\mu \mathrm{S} / \mathrm{cm})$ and nitrate concentrations of less than $0.4 \mathrm{mg} / \mathrm{L}$ as N (Denver, 1989; Hamilton and others, 1993). Many of the common constituents in fertilizers that are typically applied to fields also dissolve in water and can travel to groundwater if they leach below the root zone. Plants need a variety of nutrients to grow, including nitrogen, phosphorus, potassium, magnesium, and calcium. With the exception of phosphorus, these chemicals typically contribute to the major ions in groundwater affected by agricultural activities (Hamilton and others, 1993). In well-drained soils, phosphorus is typically bound to soils and sediments and not dissolved in water (Ator and Denver, 2015).

Nitrate is widespread throughout the surficial aquifer of the Delmarva Peninsula (Debrewer and others, 2007) and nitrate concentrations in natural groundwater rarely exceed $0.4 \mathrm{mg} / \mathrm{L}$ in the surficial aquifer of the Delmarva Peninsula (Hamilton and others, 1993). Concentrations of nitrate above natural background levels are likely impacted by anthropogenic activity (Debrewer and others, 2007). Recent studies on the Delmarva Peninsula have shown that nitrate concentrations in groundwater increased about $2 \mathrm{mg} / \mathrm{L}$ as $\mathrm{N}$ in parts of the surficial aquifer used for domestic supply from 1988 to 2001 in response to increased nitrogen applications in previous decades (Denver and others, 2004; Ator and Denver, 2015). Headwater streams on the Delmarva Peninsula, which derive most of their flow as groundwater discharge from the surficial aquifer, also show nitrate concentrations above natural levels during base flow (Ator and Denver, 2015, Denver and others, 2004).

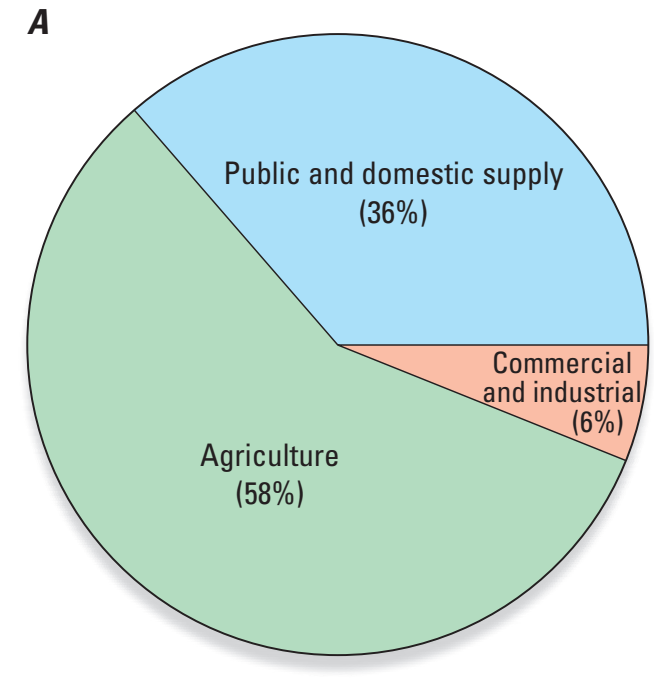

151 million gallons per day

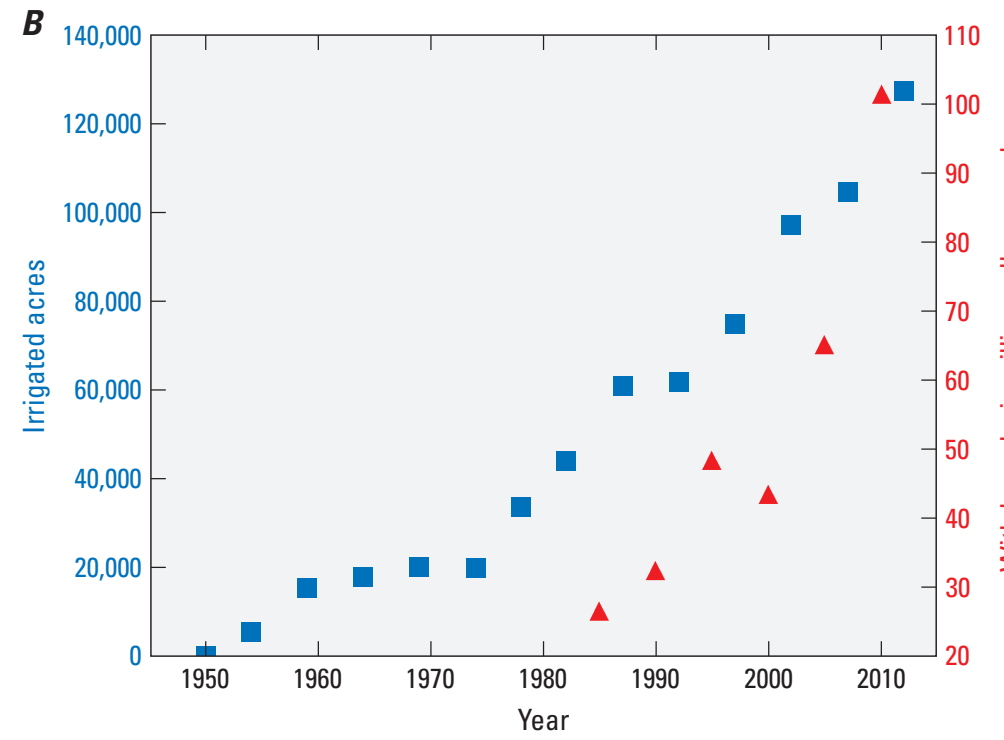

Figure 3. Groundwater use by $A$, category for the Delaware Coastal Plain 2010 (Masterson and others, 2016), and $B$, acres irrigated (U.S. Department of Agriculture, National Agricultural Statistics Service, 2012) and volume withdrawn for agricultural irrigation in the Delaware Coastal Plain (Cheryl Dieter, USGS, written commun., 2016). (\%, percent) 


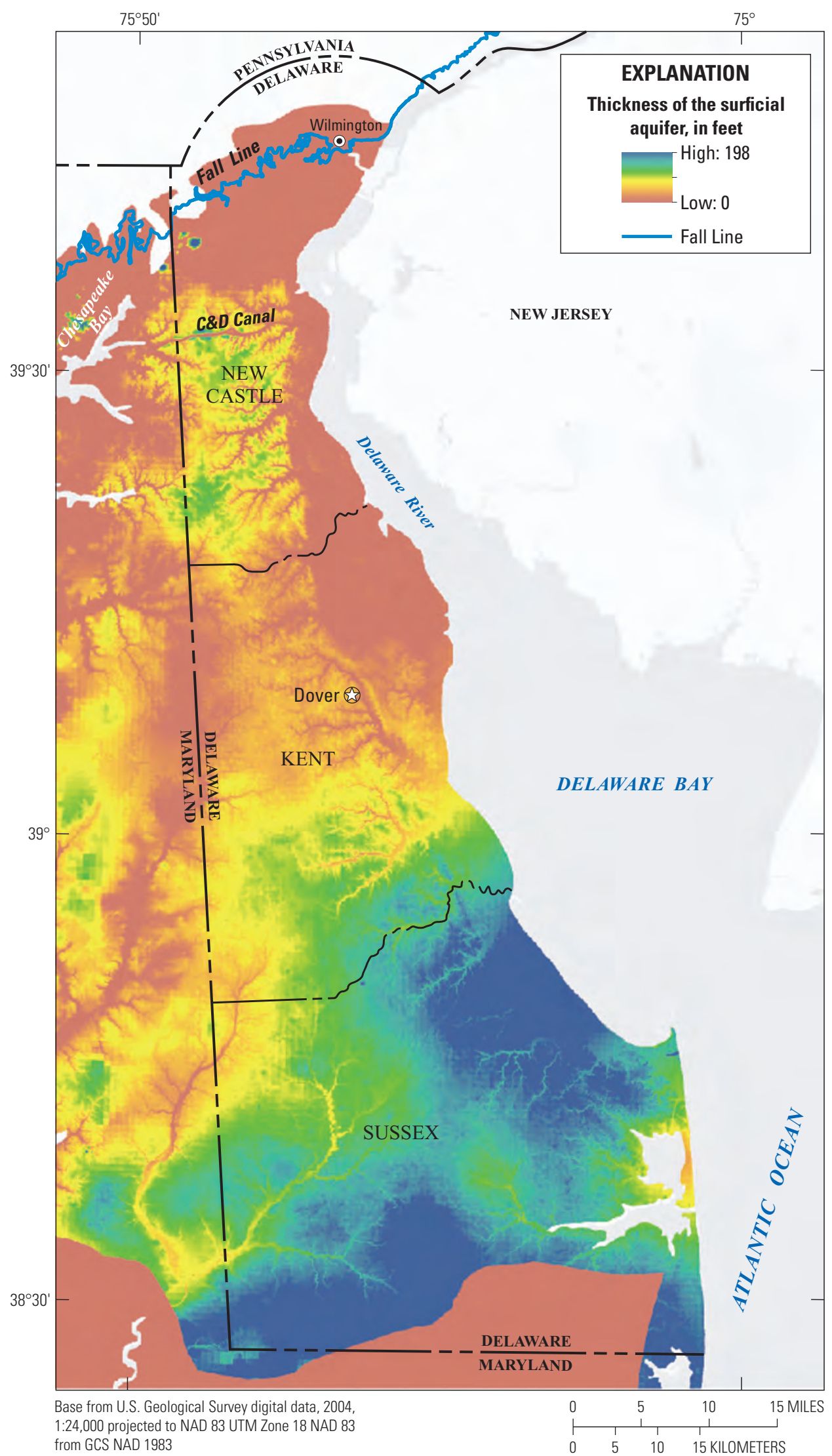

Figure 4. Thickness of the surficial aquifer in the Delaware Coastal Plain (Denver and Nardi, 2016). 


\section{Agricultural Practices, Nutrient Management, and Best Management Practices (BMPs)}

Farmers use tools such as soil tests, Pre-Sidedress Nitrate Tests (PSNTs), plant tissue sample analyses, and crop yield production history to determine a crop's nutrient needs for each soil type (Haering and Evanylo, 2006). When plants receive the correct balance of nitrogen, phosphorus, and potassium throughout the growing season, they are able to use these compounds with optimal efficiency, leaving less in the soil. Providing inadequate nutrient balance not only reduces yield, but it also reduces the plant's efficiency and can lead to nutrients going unused by the crop (Plaster, 1997). A healthier plant promotes more efficient utilization of nutrients.

Nitrogen, in particular, is an essential nutrient for plants; without it, a plant cannot grow normally. Nitrogen is a major component of chlorophyll, the molecule used by plants during photosynthesis to convert sunlight energy into sugars (Plaster, 1997). Nitrogen is also an essential element of amino acids, the building blocks of protein. Delaware has predominantly sandy soils, particularly in parts of Kent and Sussex Counties (Soil Survey Staff, 2016). Sandy soils often contain low amounts of organic materials and can be deficient in nitrogen (Shober, 2015). Because of these two factors, it is especially important to provide nitrogen in its most bioavailable form, nitrate, to crops.

Delaware farmers have been using an increasing array of BMPs to reduce nutrient loading to surface water and groundwater. For example, the use of cover crops has become increasingly widespread in Delaware, taking up nutrients from the soil during the winter months to reduce nutrient leaching to the groundwater. Modified tillage practices are used to reduce the movement of sediment and nutrients away from fields.

Cover crops are grasses, legumes, or small grains planted between crop cycles to protect and improve soil health. They protect soil by reducing erosion, improving stability, and managing soil moisture. Cover crops also benefit the larger ecosystem by increasing biodiversity, attracting pollinators, suppressing weeds, and providing forage (Nolan and others, 2002). Lastly, cover crops also promote soil health by increasing organic matter, redistributing nutrients within the soil, fixing nitrogen, and removing excess nutrients (Nolan and others, 2002). Legumes such as field peas, clover, and vetch are excellent at fixing nitrogen in soil, and grass cover crops such as wheat, rye, and barley are particularly good at removing excess nutrients from soil (U.S. Department of Agriculture, Natural Resources Conservation Service, 2014).

Farmers have also altered their tillage practices in order to minimize the movement of nutrients away from their intended use locations. Tillage is the agricultural practice of cultivating or preparing soil for planting. Conventional or traditional tillage practices involve the mechanical disturbance of the top layer of soil, and the mixing of plant residues left after harvest. Conventional tillage is defined as leaving 15 percent or less crop residue on a field after harvest (Delaware Department of Natural Resources and Environmental Control,
2015). Although this practice has benefits, such as insect and weed control, conventional tillage leaves soil exposed. This can increase soil erosion and sediment runoff, and increases soil compaction, which facilitates surface-water runoff.

In contrast, conservation tillage practices involve the minimal disturbance of soil and plant residues that remain on a field after harvest. Essentially, the soil remains undisturbed after harvest and is minimally disturbed during the planting of the next crop. Conservation tillage is defined as leaving a minimum of 30 percent crop residue on a field (Delaware Department of Natural Resources and Environmental Control, 2015). To adapt to this different practice, farmers use specifically designed equipment that enables them to drill or plant seeds while minimizing the disturbance of soil and existing crop residue. This practice has many benefits, including the preservation of soil moisture; the reduction of soil erosion from wind, rain, or other forces; and an increase in the organic matter content in soil. By minimizing soil erosion, conservation tillage decreases the movement of nutrients bound with this soil off of the field in overland runoff. By increasing organic matter content in the soil, conservation tillage provides increased material to bind nutrients to the soil, minimizing the leaching of nutrients through the soil into the shallow groundwater.

In Delaware, these BMPs are being implemented in all three counties. For example, in 2015, conventional tillage was used on 11.6, 21.5, and 22.4 percent of New Castle County, Kent County, and Sussex County farmland, respectively. In contrast, conservation tillage practices were used in 81.7, 72.5, and 65.9 percent of New Castle County, Kent County, and Sussex County farmland, respectively. Cover crops were used on 24, 43, and 32.5 percent of New Castle County, Kent County, and Sussex County farmland, respectively (Delaware Department of Natural Resources and Environmental Control, 2015).

The goal of using cover crops and conservation tillage, along with estimating nutrient budgets prior to the application of fertilizer, is to minimize the amount of land-applied nutrients available to move into surface water and groundwater in Delaware.

\section{Methods of Study}

A new network of wells was designed from wells in two active groundwater-monitoring networks maintained by the DDA and the USGS in the unconfined surficial aquifer of the Delaware Coastal Plain. Wells were included in the network on the basis of depth, previously known oxic conditions, and the proximity to agricultural land use. Water from wells was analyzed to establish geochemical conditions in 2014 and identify patterns in water quality in the unconfined surficial aquifer of the Delaware Coastal Plain. Land use and soils near the wells are summarized concurrently with the groundwaterquality results, creating a snapshot of land use and water quality that will be used to compare with future conditions. 


\section{Network Design}

In 1995, the DDA designed a shallow groundwater-monitoring network with the assistance of the Delaware Geological Survey (DGS) (Blaier and Baxter, 2000). The network consists of 104 dedicated monitoring wells located throughout the State south of the Chesapeake and Delaware Canal (C\&D Canal, fig. 1). The wells are primarily used to monitor the State's shallow groundwater for pesticides of interest that are registered for use in the State.

With a few exceptions, the DDA pesticide monitoring wells are located on roadsides in State rights-of-way. Wells are screened in the Columbia aquifer. All wells are considered shallow, with the bottom of screen depths less than 40 feet (ft) below ground surface. Well depths range from $8.35 \mathrm{ft}$ to $38.70 \mathrm{ft}$. The average completion depth for all 104 currently active monitoring wells is $16.10 \mathrm{ft}$. The monitoring wells were screened across the water-table surface at the time of drilling.

Since the network was initially designed to monitor groundwater for agricultural herbicides, all of the monitoring wells are located below the C\&D Canal in the Delaware Coastal Plain, where most of the State's agricultural land is located. This requirement generally excludes land above the C\&D Canal, areas within incorporated towns and cities, and areas along the coast where land is largely marsh and other wetlands.

A subset of wells from the DDA network and from an agricultural land-use network developed for the USGS National Water-Quality Assessment (NAWQA) Project were included in the new network. The existing USGS network was designed to assess water quality in the surficial aquifer of the Delmarva Peninsula (Debrewer and others, 2007; Koterba and others, 1990; Shedlock and others, 1993) as part of NAWQA. A subset of wells from the NAWQA network that are located in Delaware, and screened within oxic parts of the shallow unconfined aquifer, were selected for inclusion in the new network. In total, 8 wells from the USGS network and 40 wells from the DDA pesticide network were sampled during fall 2014 (fig. 1, table 1). Well depths ranged from $11 \mathrm{ft}$ to $34 \mathrm{ft}$.

\section{Sample Collection and Analysis}

Water samples were collected using methods outlined in the USGS National Field Manual for the Collection of WaterQuality Data (U.S. Geological Survey, variously dated). The sample collection was designed to represent shallow, oxic groundwater conditions in the Delaware Coastal Plain from October through December 2014. Prior to sampling, at least three well volumes were purged using a Fultz sp300 submersible pump to remove standing water, and geochemical and physical field parameters were monitored with a YSI 6920 sonde until stable conditions were reached. For this study, stable geochemical conditions were defined as five successive 5 -minute measurements of $\mathrm{pH}$ ( \pm 0.1 units), water temperature ( \pm 0.2 degrees Celsius), specific conductance $( \pm 3$ percent $)$, dissolved oxygen $( \pm 0.3 \mathrm{mg} / \mathrm{L})$, and turbidity $( \pm 10$ percent $)$.
Well Pf41-02 recharged too slowly for standard purging procedures. This well was purged and allowed to recover to 90 percent of the original water level before measuring field parameters and sample collection. Samples were collected using Teflon tubing and a 0.45 -micrometer capsule filter inside a clean sampling chamber. Filtered water samples for inorganics analysis were preserved using nitric acid to a pH below 2 .

All samples were maintained at a temperature below 4 degrees Celsius in a sealed cooler during shipment to the laboratory.

Samples from all wells were analyzed for major ions and nutrients at the USGS National Water Quality Laboratory (NWQL) in Denver, Colorado using methods described in Fishman (1993). Samples from 25 wells also were analyzed for trace atmospheric gases, including sulfur-hexafluoride, nitrogen, argon, carbon dioxide, methane, and oxygen. Gas analyses were conducted at the USGS Chlorofluorocarbon Laboratory in Reston, Virginia and recharge age determined using methods described by Busenberg and Plummer (2000). Alkalinity and bicarbonate concentrations were determined in samples with $\mathrm{pH}$ greater than 4.5 using field electrometric titrations on filtered samples using the inflection point method (Rounds, 2006). Where $\mathrm{pH}$ was below 4.5, alkalinity and bicarbonate concentrations were assumed to be zero.

\section{Quality Control}

Quality-control samples were collected to evaluate and estimate potential contamination bias and measurement variability from water-quality data-collection processes (Koterba and others, 1995). An equipment blank was collected prior to sampling; four field blanks and four replicates were collected during field activities at selected wells. Field collection procedures for quality-control samples were established using the USGS National Field Manual (U.S. Geological Survey, variously dated) in a manner consistent with procedures for the acquisition of environmental samples. This evaluation of quality-control samples included the review of analytical data, field practices, reported environmental concentrations, and timing of quality-control activities.

\section{Age Dating}

Recharge dates for groundwater samples were estimated on the basis of measured concentrations of sulfur hexafluoride $\left(\mathrm{SF}_{6}\right)$, and dissolved nitrogen, argon, carbon dioxide, methane, and oxygen (Busenberg and Plummer, 2000). Industrial production of $\mathrm{SF}_{6}$ started in the 1950 s and increasing concentrations in the atmosphere have been documented since 1978 (Maiss and Brenninkmeijer, 1998). $\mathrm{SF}_{6}$ can be used to date groundwater that is in equilibrium with the atmosphere when it is recharged. $\mathrm{SF}_{6}$ is a good tracer for young groundwater (recharged after 1970), however, its usefulness as a groundwater age tracer decreases for older waters. For this study, field conditions at 25 wells were suitable to sample for $\mathrm{SF}_{6}$. 


\section{Data Analysis}

Statistical methods were selected to identify patterns in shallow, oxic groundwater from unconfined wells near agricultural land use. Nonparametric Spearman correlation analysis (Helsel and Hirsch, 2002) was used to identify wells with similar geochemical characteristics based on analytical results of $\mathrm{pH}$, specific conductance, dissolved oxygen, silica, chloride, bicarbonate, sulfate, magnesium, calcium, potassium, sodium, and nitrate. The Spearman correlation matrix for all wells was used as input for an agglomerative hierarchical cluster analysis using Ward's method to minimize the variance between clusters (Ward, 1963). The Python library SciKitLearn (Pedregosa and others, 2011) was used to apply the cluster analysis. Groups of wells determined by cluster analysis were used to summarize water-quality results and describe the variability of relevant physical properties (land use, soils, and aquifer thickness). Non-parametric KruskalWallis multiple comparison tests were done using the pgirmess package in the R software (Giraudoux, 2017) to determine if populations of selected constituents and land cover were significantly different by geochemical groups derived by correlation and cluster analysis. Land use and land cover from the State of Delaware (2007) and soils were documented on a well-by-well basis within an approximately 1,640-ft radius of each well through a Geographic Information System buffering and overlay procedure that extracted land-use polygons for summary. Selected water-quality constituents were compared directly to physical properties. Trilinear diagrams were constructed to illustrate major cations and ions in various water types identified within the network. Chloride to bromide mass ratios were calculated to identify possible sources of chloride in groundwater samples.

\section{Factors Affecting Variability}

The quality-control procedures included five blank samples to test for potential equipment contamination and four replicate samples to test for reproducibility of results. Detectable concentrations of ammonia, chloride, and sulfate were found in blank samples, but were within twice the respective laboratory detection limits. Manganese was detected at 0.54 micrograms per liter $(\mu \mathrm{g} / \mathrm{L})$ in the pre-study equipment blank, which is greater than the laboratory detection limit of $0.20 \mu \mathrm{g} / \mathrm{L}$. For replicate samples, a relative percent difference (RPD) between environmental and replicate results of 20 percent was used as an indication of variability from sampling procedures for this study. A single constituent, iron, exceeded the 20-percent RPD criteria, at $6.1 \mu \mathrm{g} / \mathrm{L}$ for the replicate and $<4 \mu \mathrm{g} / \mathrm{L}$ for the environmental sample, however the mean RPD for all replicate iron samples was 8.9 percent and within the study criteria. Quality-control results show there was not significant variability or bias that would affect the interpretation of water-quality results for this study.

The quality of water in the surficial aquifer of the Delaware Coastal Plain is influenced by the availability of dissolved ions from natural and human sources, and by geochemical factors that affect the fate and transport of these ions. Dissolved oxygen concentrations can control geochemical transformations, and in the surficial aquifer, waters are typically considered oxic, with dissolved oxygen concentrations above $0.5 \mathrm{mg} / \mathrm{L}$ (McMahon and Chapelle, 2008). Understanding redox conditions is important because under oxic conditions redox-sensitive parameters (such as nitrate) are stable. In poorly drained settings in the surficial aquifer, anoxic conditions (dissolved oxygen less than $0.5 \mathrm{mg} / \mathrm{L}$ ) exist, although these were avoided by design in this study. Land use and chemicals applied on the land surface play an important role in surficial groundwater quality. Soil conditions and aquifer properties also can affect recharge rates and groundwater quality. Groundwater age can influence the quality of groundwater, depending on the land use at the time recharge occurs. These and other factors combine to determine the spatial variability in groundwater quality in the surficial aquifer of the Delaware Coastal Plain.

\section{Groundwater Age}

Apparent groundwater ages of samples for which dissolved gases were measured ranged from 1 to 20 years (table 2). These results are consistent with other age tracer results in similar settings (Clune and Denver, 2012; Debrewer and others, 2008) and demonstrate that shallow wells screened just below the water table typically produce relatively young groundwater. Recently recharged groundwater, such as the groundwater observed in this study, is where expected changes in nitrate concentrations would be observed first, since it represents the start of the groundwater-flow paths to streams in the Delaware Coastal Plain.

\section{Land Use}

Agriculture, followed by forests, is typically the predominant land-cover type near the network wells. Land-cover data used in this analysis were from the State of Delaware (2007). The land-cover data for the entire State are made up of 33 classes. These data were used to summarize the land use in a 1,640-ft-radius circular buffer around each well. When summarized and grouped into four categories by well location, of the 48 wells sampled, 38 had a majority land-cover type of cropland, 6 had urban, 3 had forest, and 1 had wetland. 


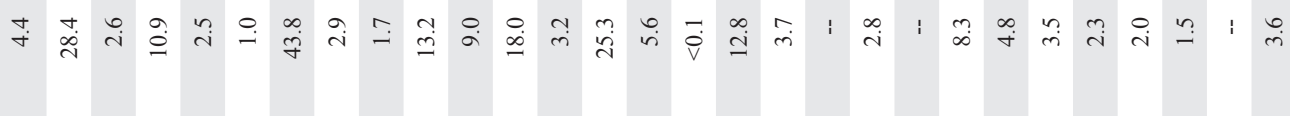

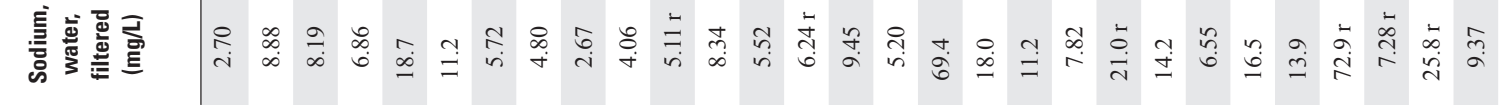

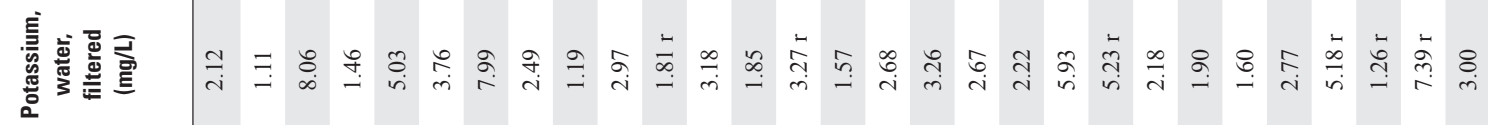

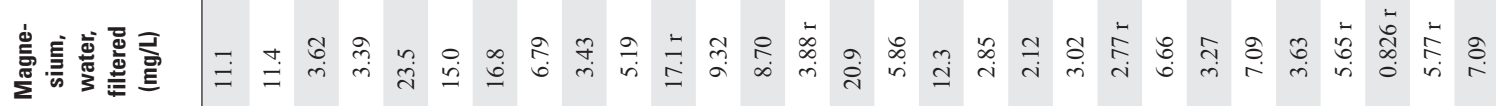

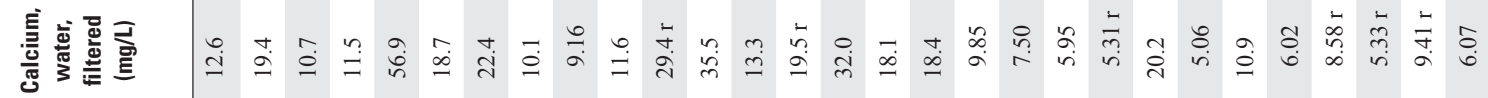

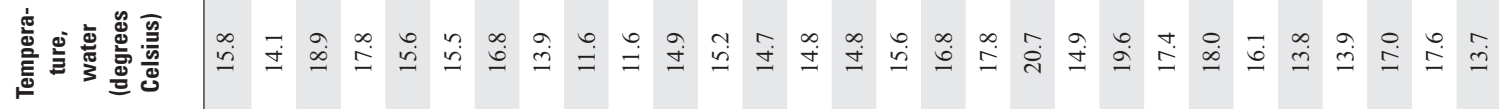

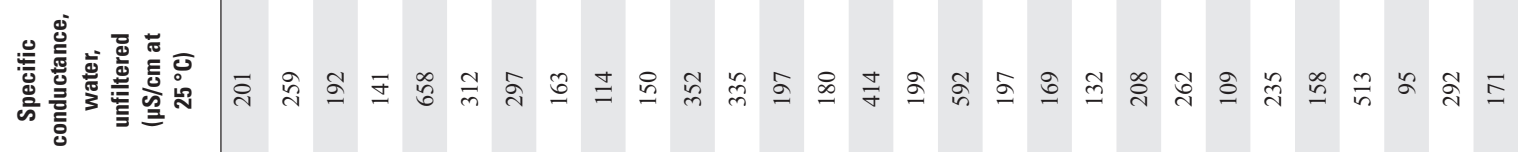

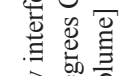

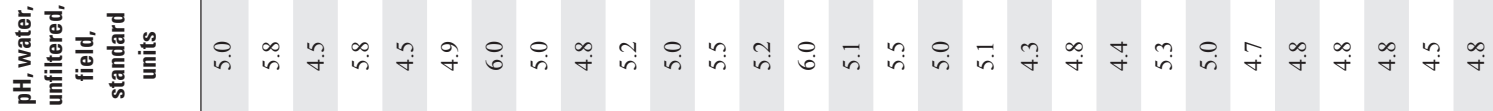
胥

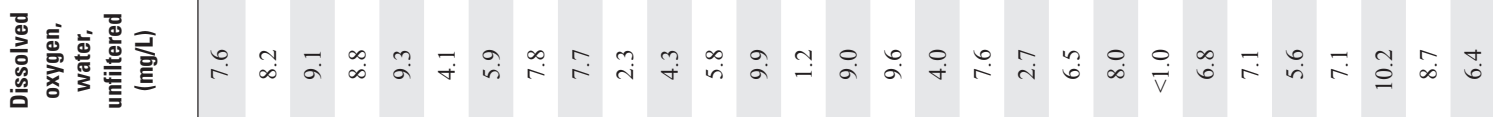




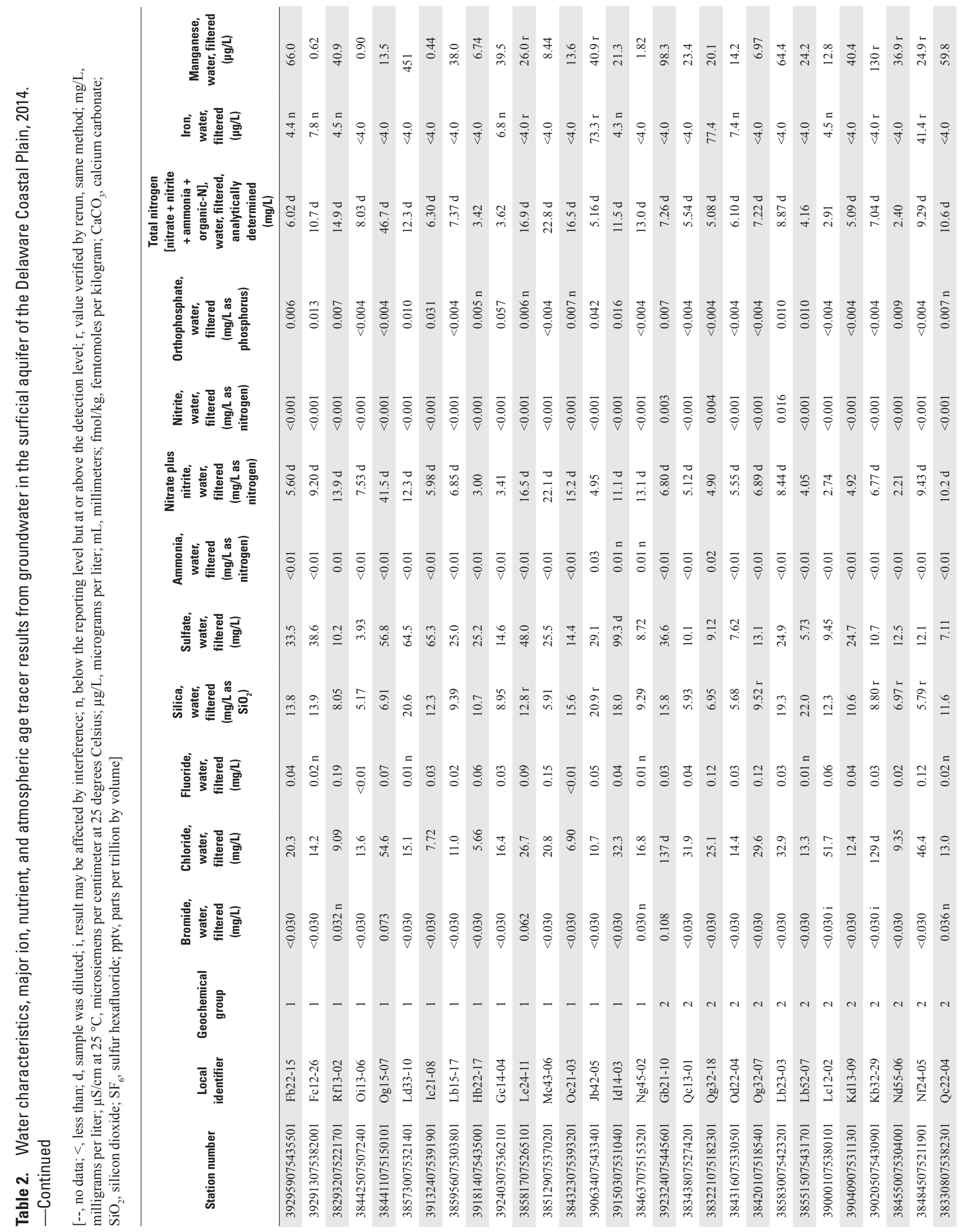




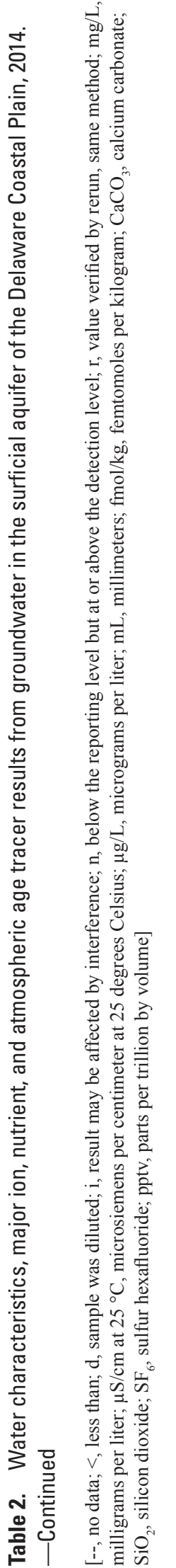

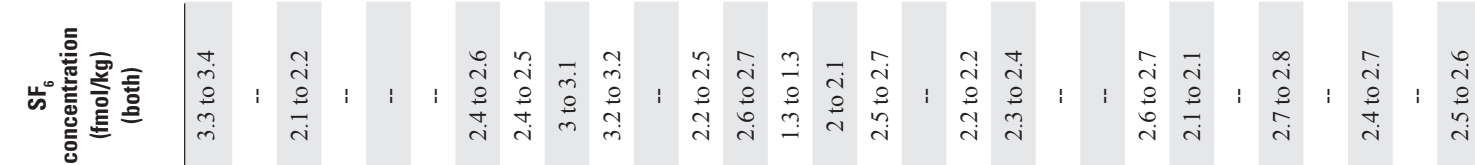

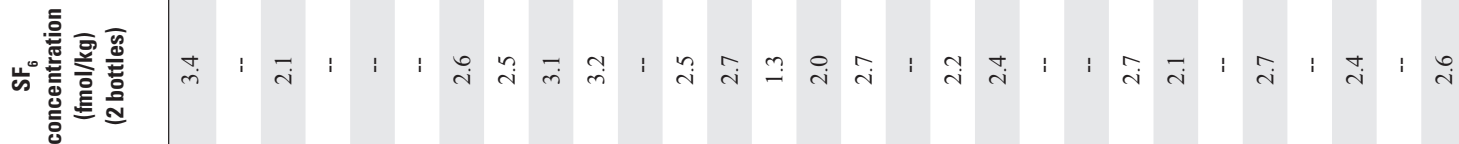

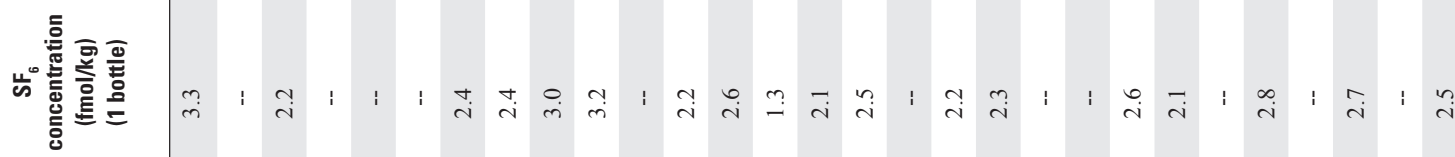

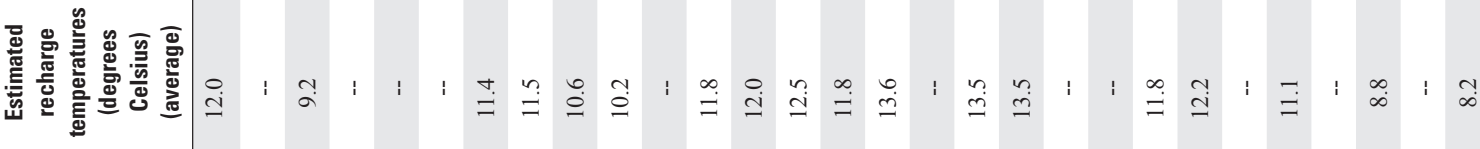

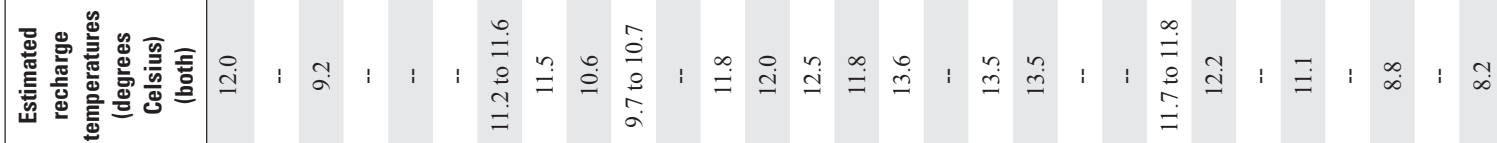

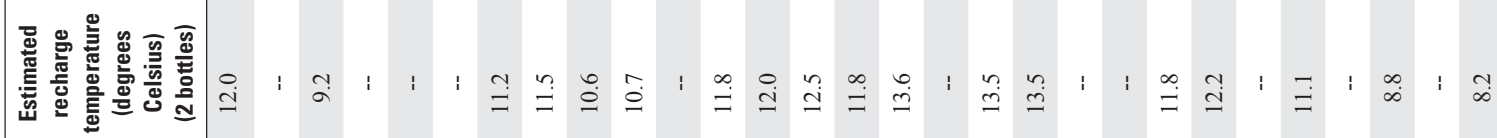

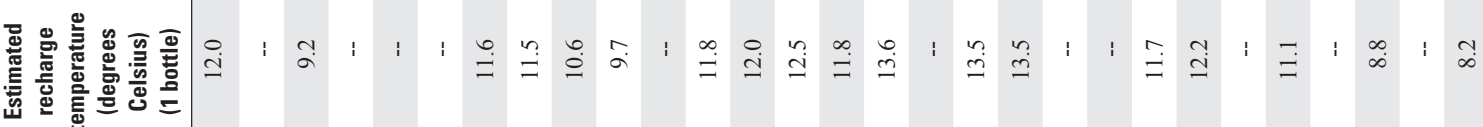

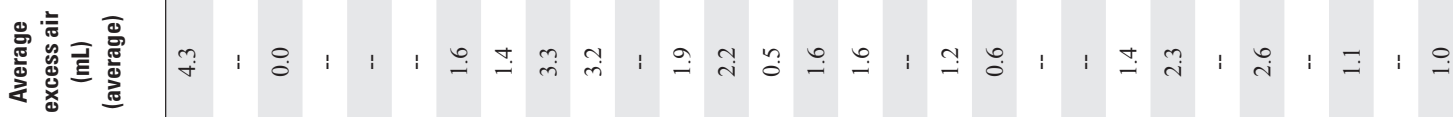

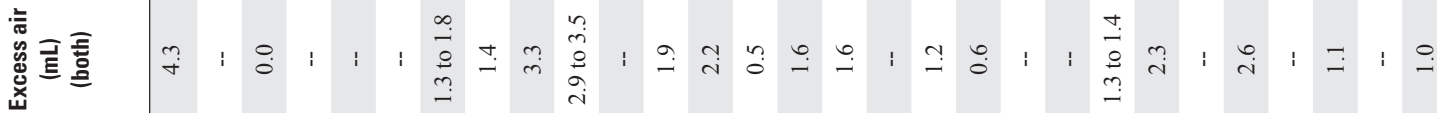

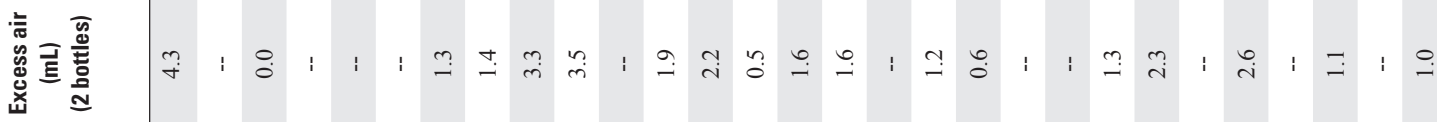

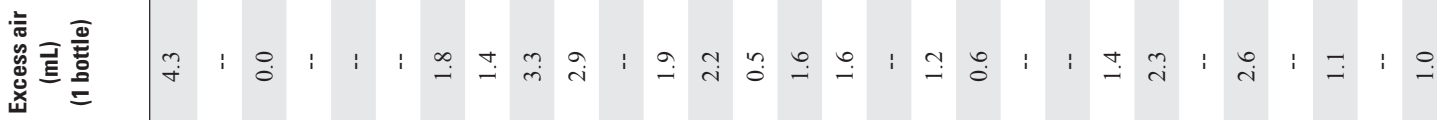

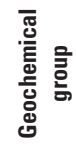

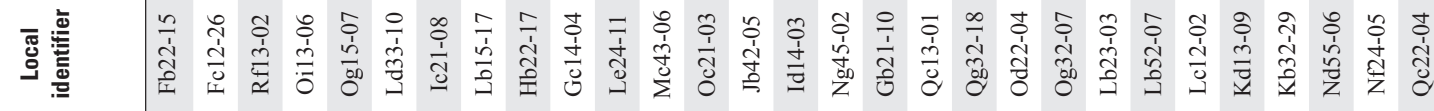

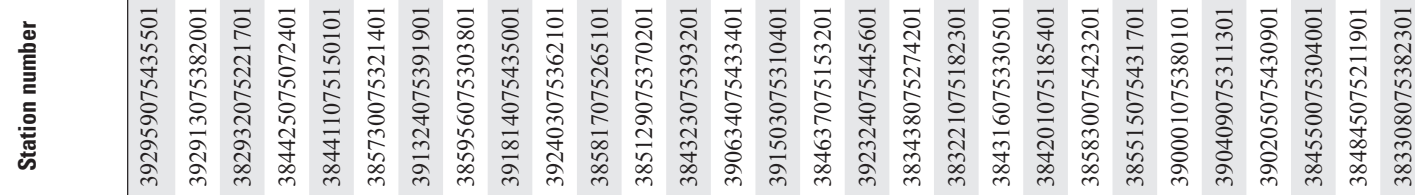




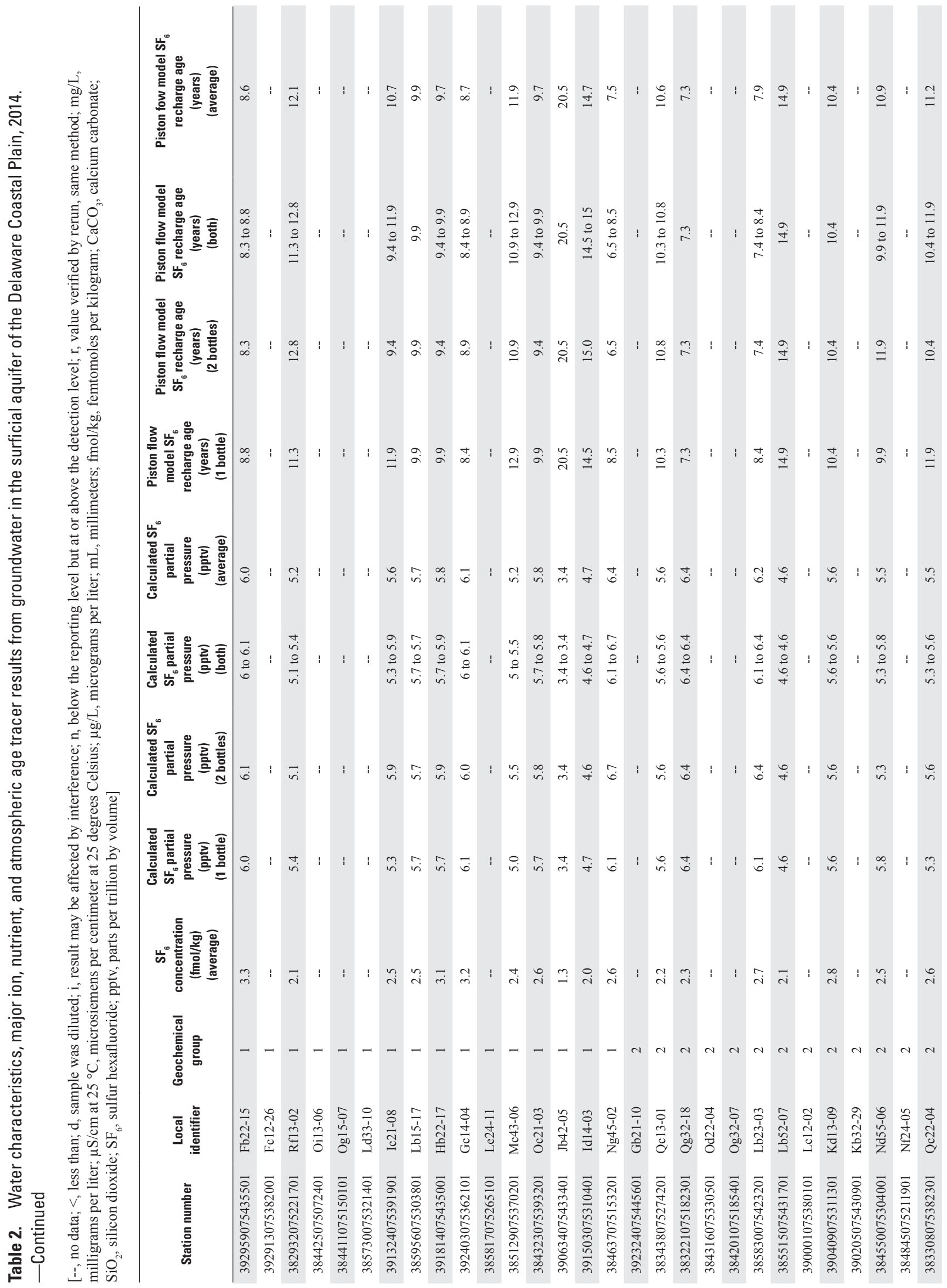




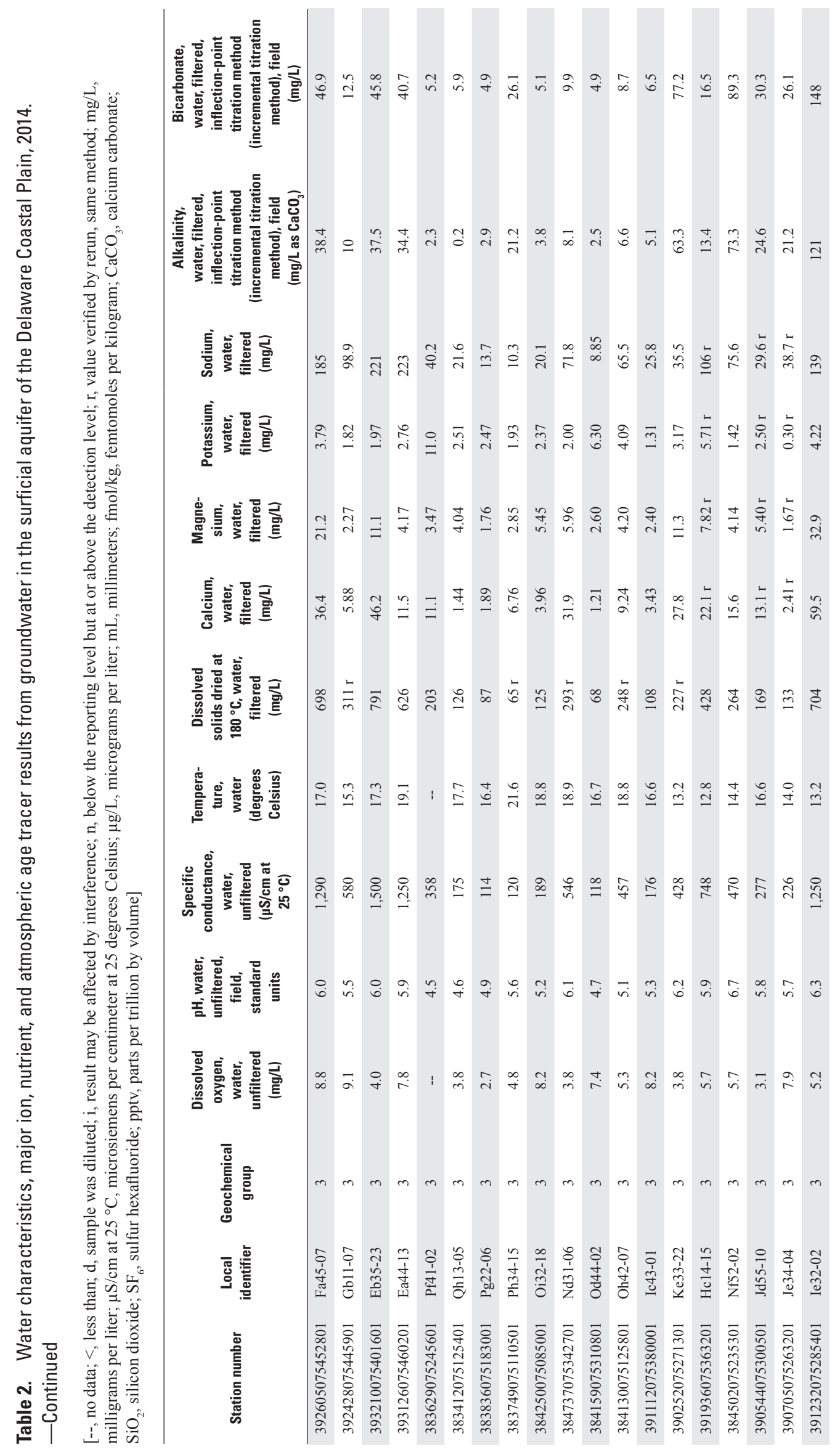




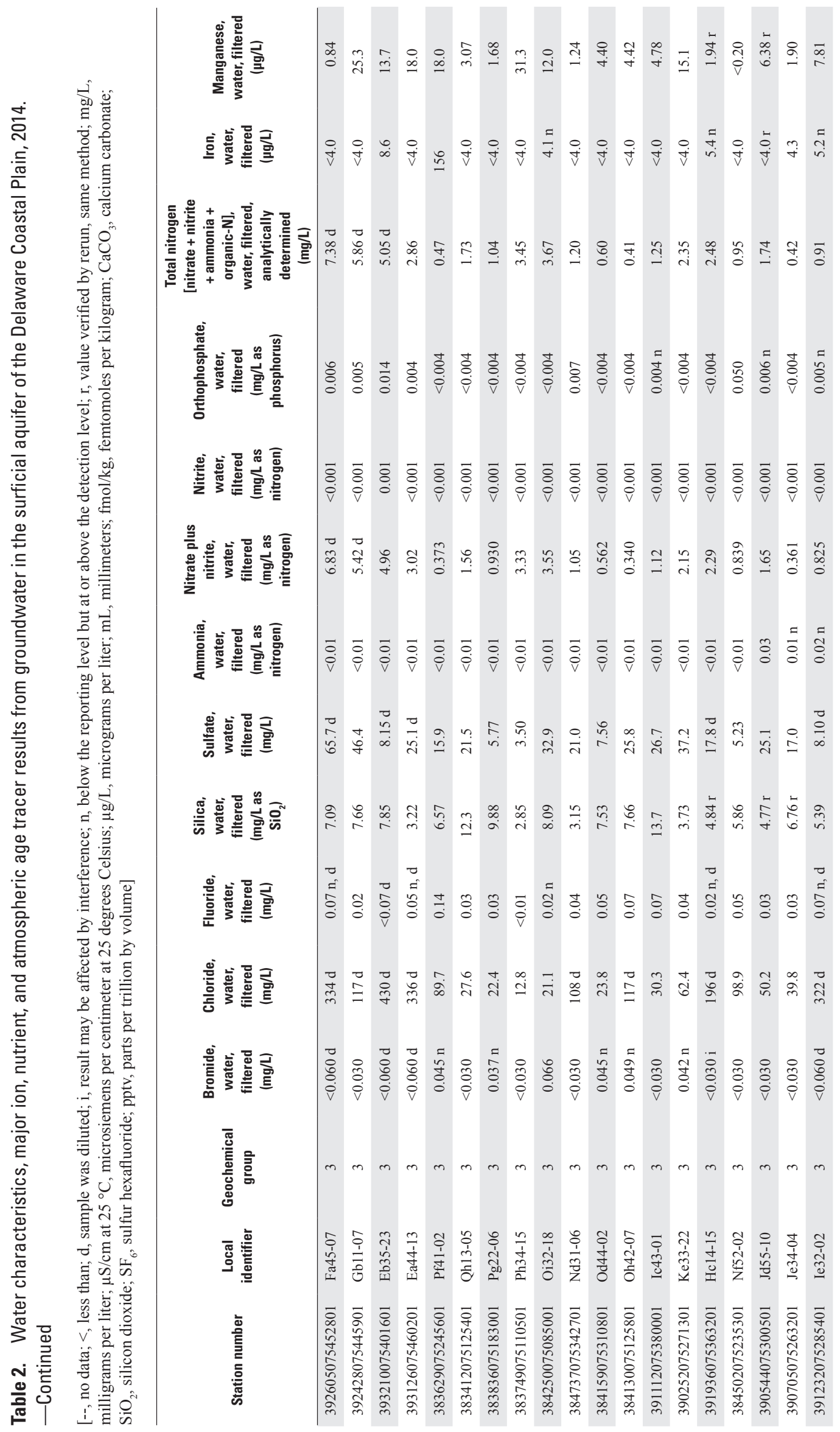



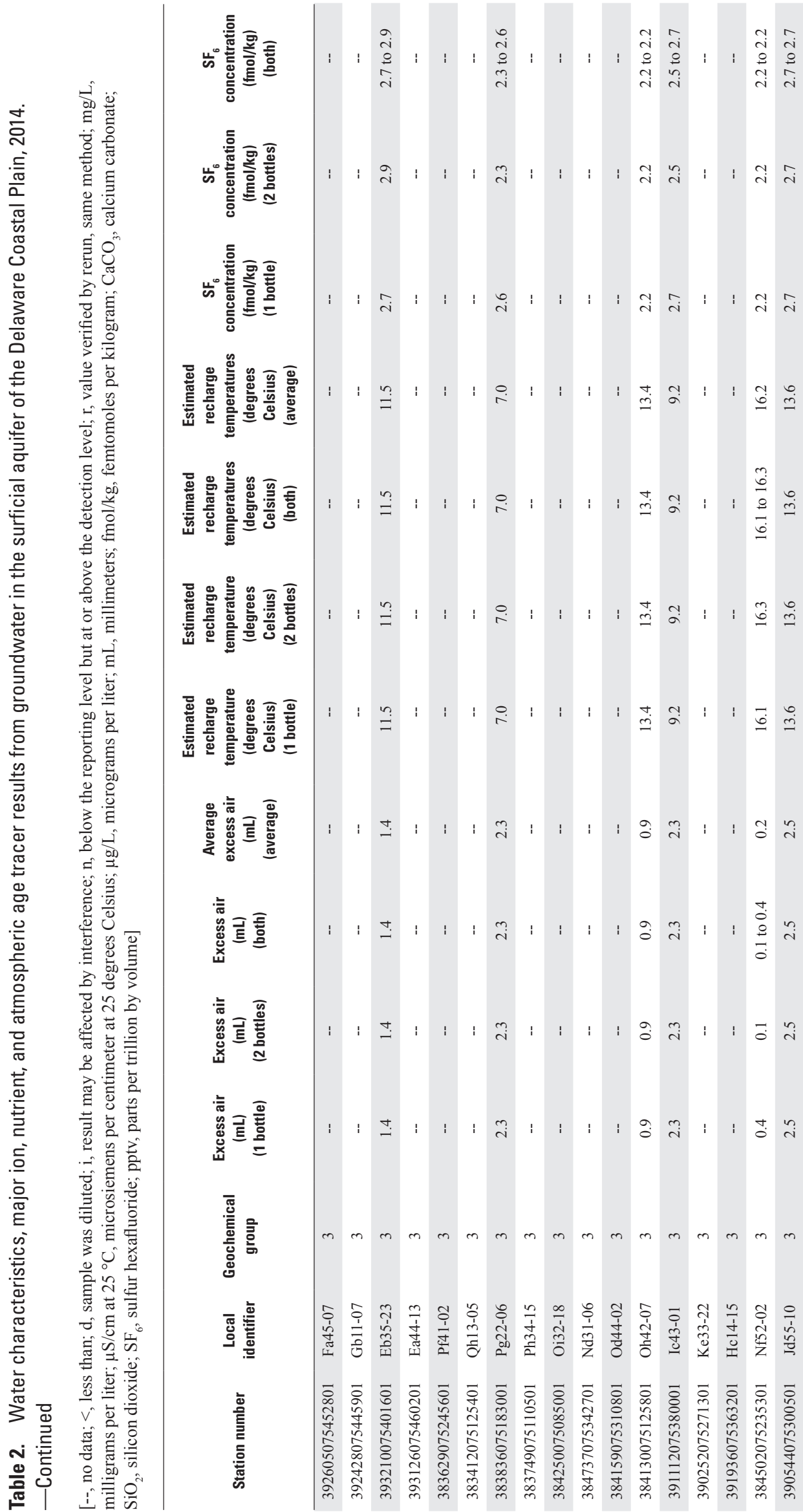

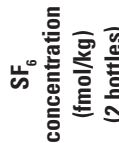

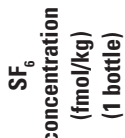

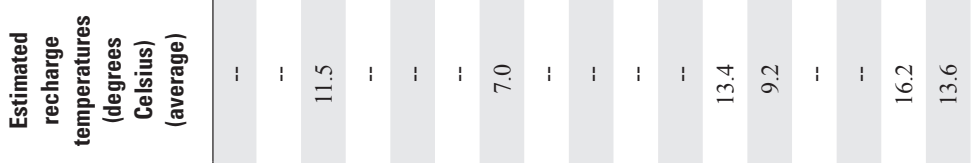

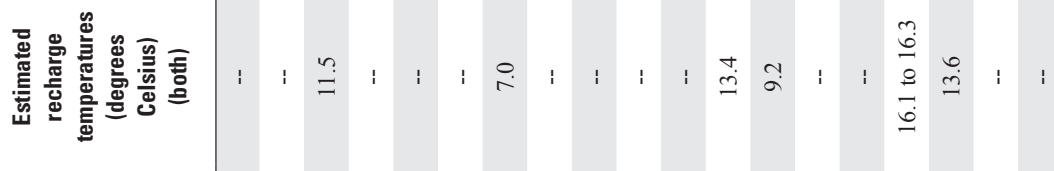

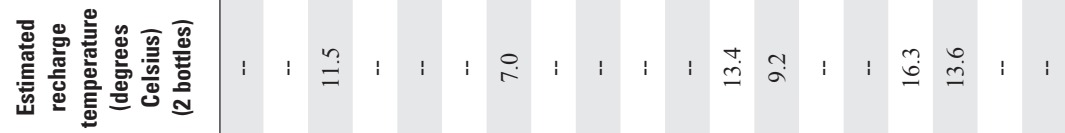

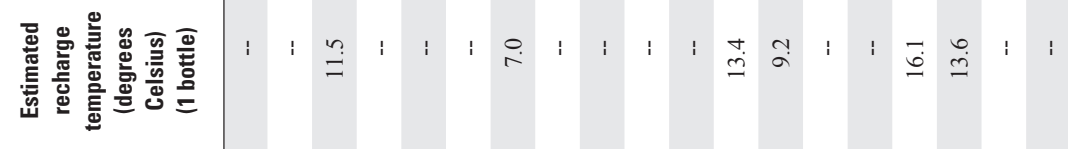

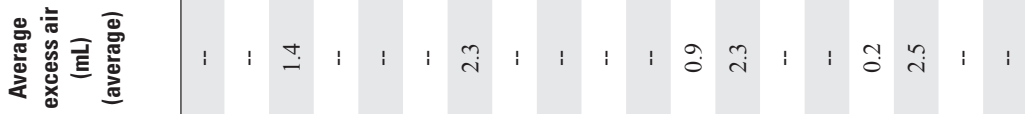

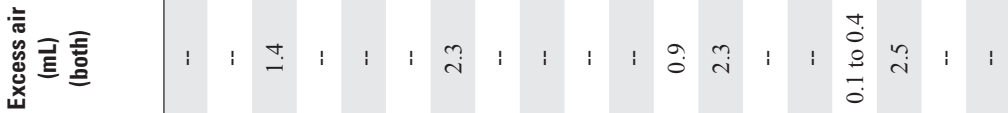

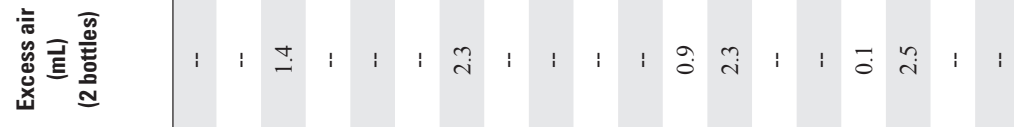

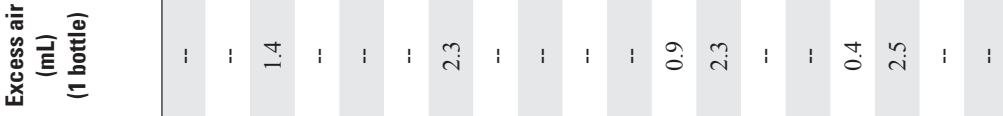

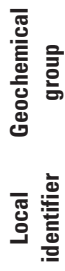

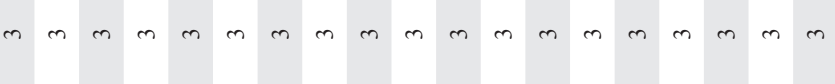

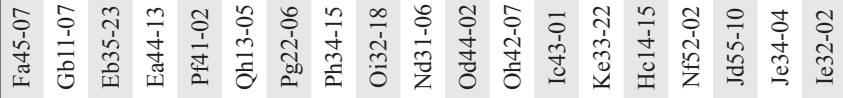

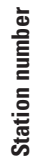

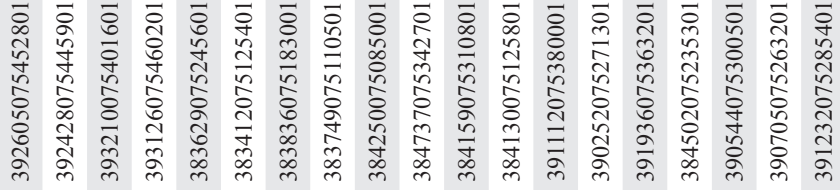




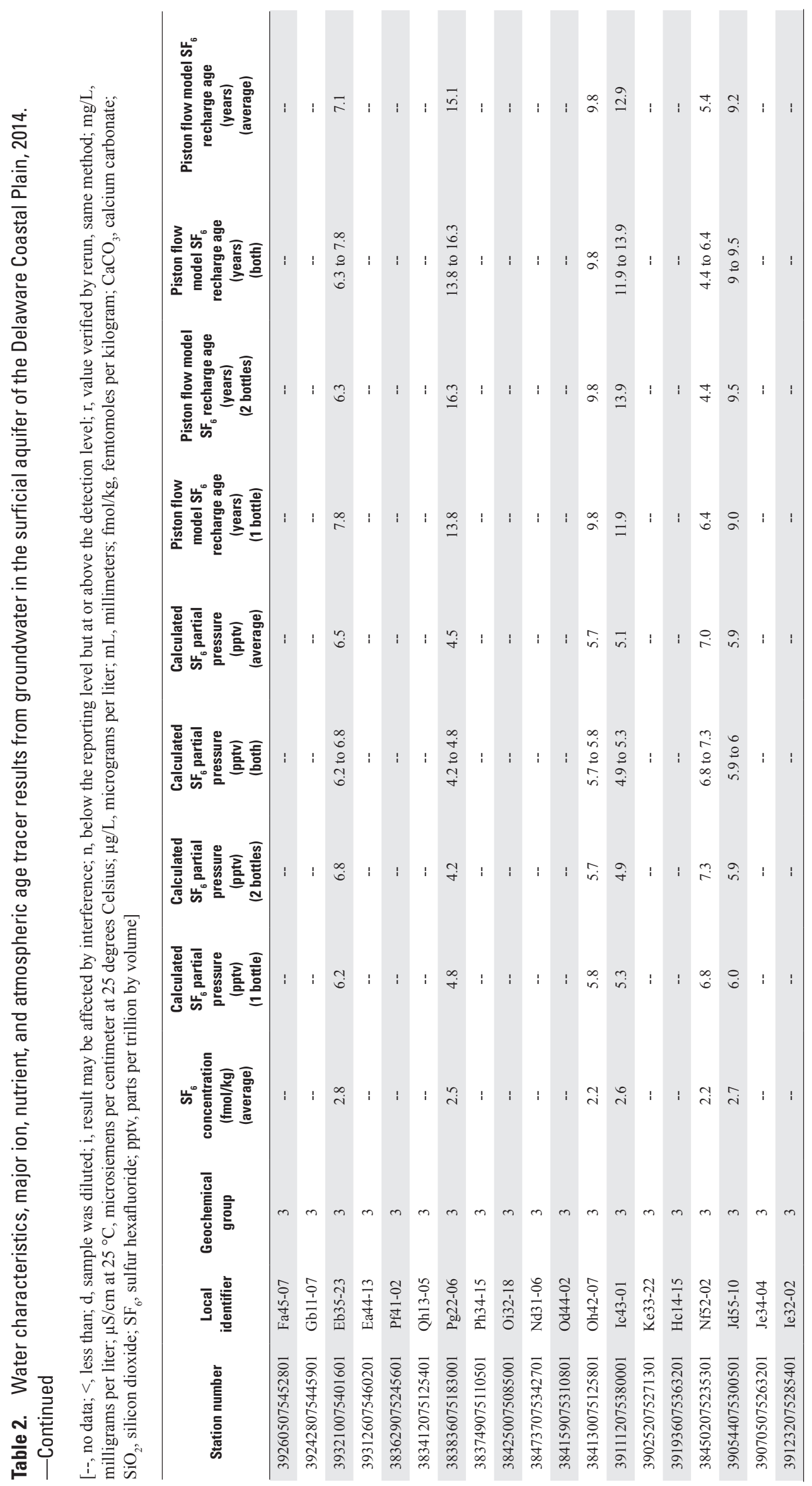




\section{Soils}

Soils data were extracted on an individual well basis using a similar buffer and extract methods as those used for the land-cover data. Soils data came from the Gridded Soil Survey Geographic (gSSURGO) database (Soil Survey Staff, 2016) and were downloaded from the U.S. Department of Agriculture's Geospatial Data Gateway. Surficial soils around the wells were mostly sandy with 46 of the 48 sampled wells having sand content greater than 50 percent. Soils at all wells had low clay content with none having more than 18.5 percent clay.

\section{Well Depth and Aquifer Position}

Surficial aquifer thickness at each well was determined using a simple overlay where well locations were intersected with an aquifer thickness dataset (Denver and Nardi, 2016). The dataset maps the thickness of the surficial unconfined aquifer, including from the land surface and unsaturated zone to the bottom of sediments of geologic units identified as part of the surficial aquifer. The thickness of the surficial aquifer may have impacts on groundwater-flow paths and the potential for denitrification. Wells in this study were mostly located in areas of relatively thick aquifer (table 1), with a mean thickness for all wells of $68.9 \mathrm{ft}$. The thickness range of all wells was $117 \mathrm{ft}$, with a minimum of $11 \mathrm{ft}$ and a maximum of $128 \mathrm{ft}$.

\section{Water Quality in the Surficial Aquifer}

Three groups of wells with similar properties were derived using Spearman's rank correlation and cluster analysis (table 2, fig. 5A). A geographic pattern (fig. 5B) is not evident from this analysis; however, land use and geochemical properties are similar within groups. These groups are useful in describing some of the variability in groundwater quality and may facilitate more detailed statistical analysis in future studies. The patterns observed in these three groups are described below.

The major-ion composition of groundwater (table 3 ) in agricultural areas of Delaware consists of two end-member water types (fig. 6) that reflect the spatial variability associated with land use and land cover, practices applied on the land, soils, and aquifer properties. Overall, the predominant cations are sodium and calcium, whereas the predominant anions are chloride and nitrate, consistent with previous studies in the Coastal Plain (Ator, 2008; Ator and Denver, 2015). However, within the geochemical groups, there are strong differences between major ions in groups 1 and 3. Group 1 is a calciummagnesium-nitrate water type (fig. 6), typically identified as an agricultural signature in the Delmarva Peninsula (Böhlke, 2002). Group 3 is a sodium-potassium-chloride water type and group 2 appears to be a mixture of groups 1 and 3 (fig. 6).

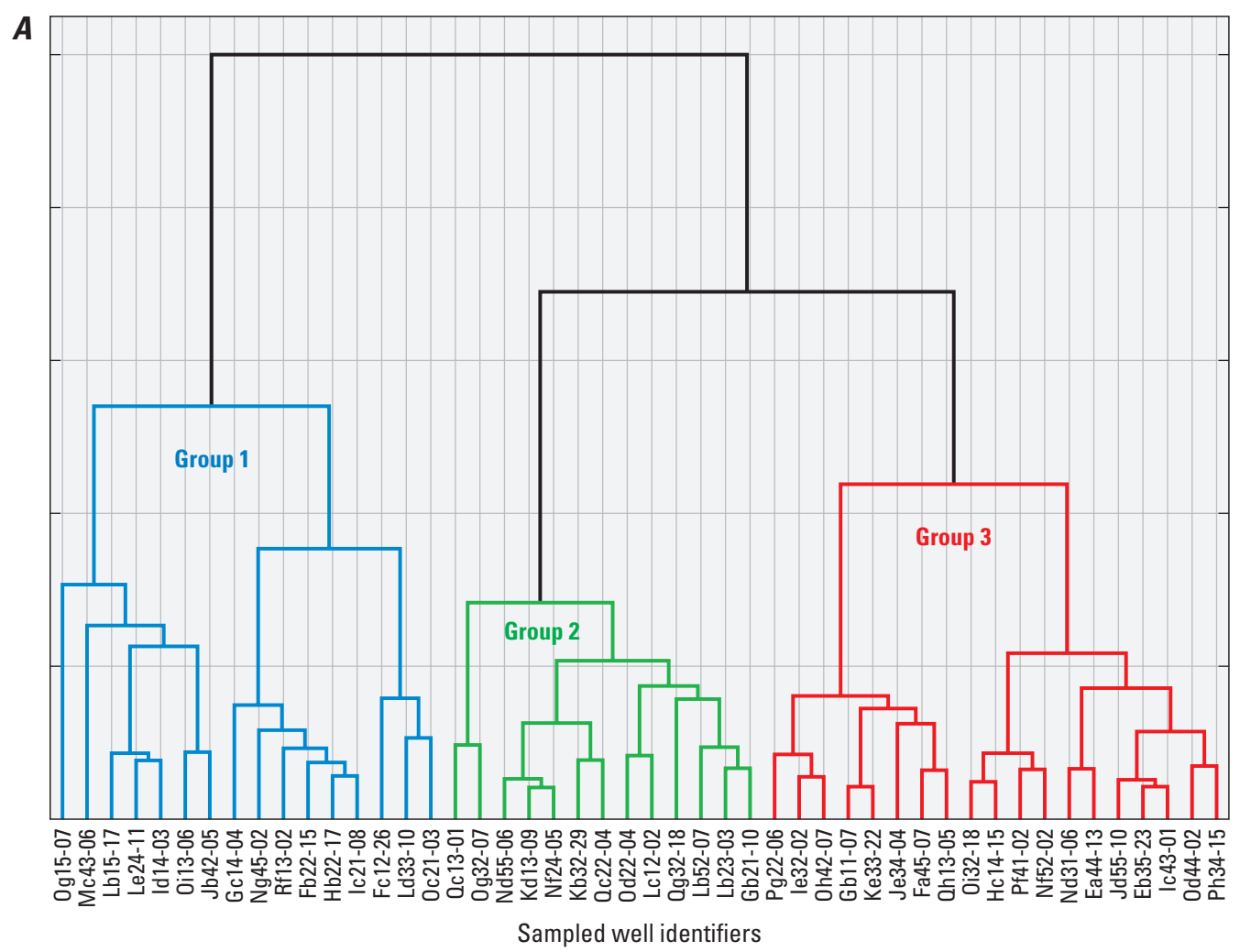

Figure 5. Results of correlation and cluster analysis, $A$, dendrogram showing the grouping of wells by correlation and cluster analysis, and $B$, the spatial distribution of geochemical groups. 


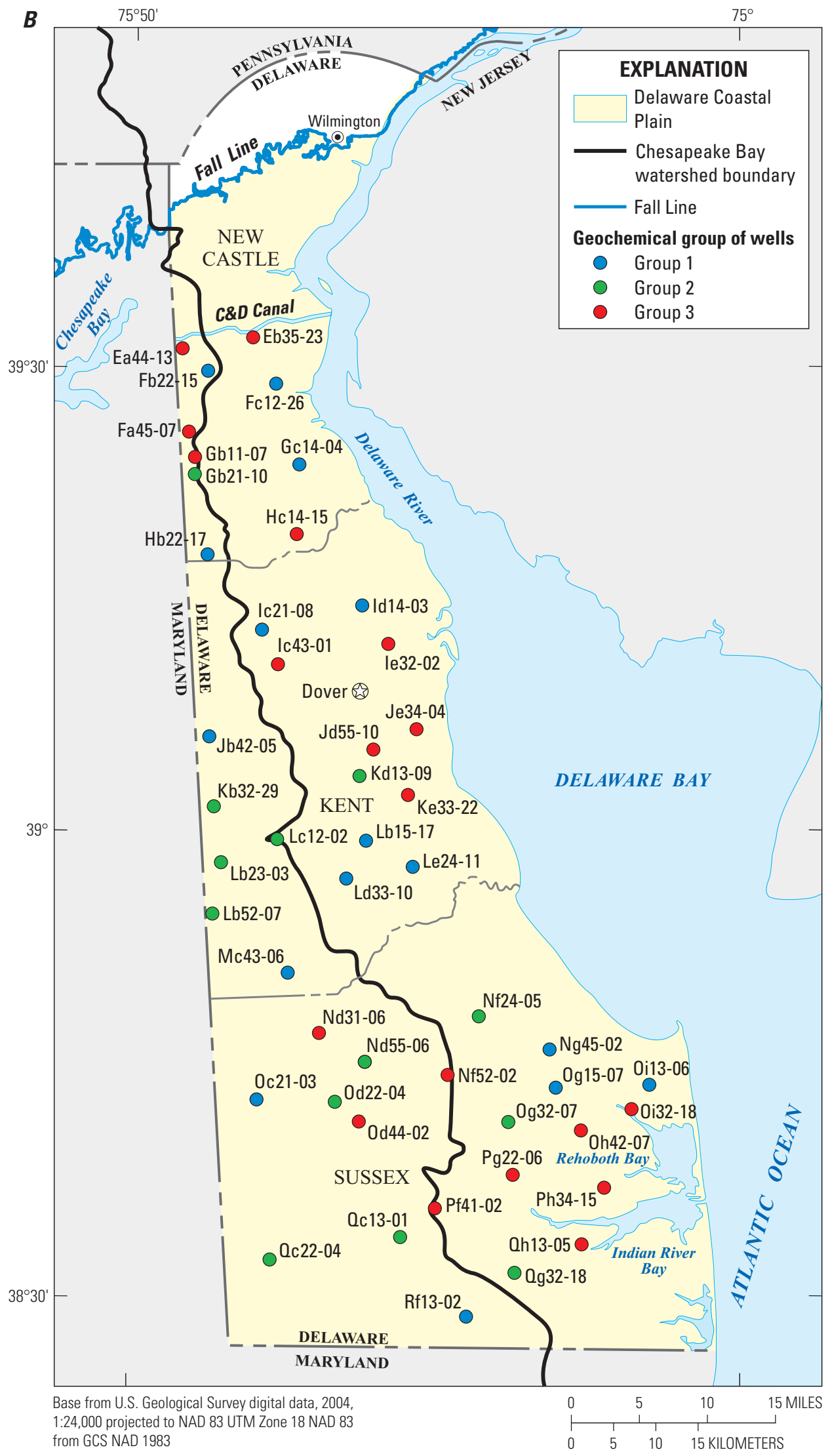

Figure 5. Results of correlation and cluster analysis, $A$, dendrogram showing the grouping of wells by correlation and cluster analysis, and $B$, the spatial distribution of geochemical groups.-Continued 
Table 3. Summary statistics for selected physical properties and major ions and elements of groundwater in the surficial aquifer of the Delaware Coastal Plain, 2014.

$[\mu \mathrm{S} / \mathrm{cm}$, microsiemens per centimeter at 25 degrees Celsius; $\mathrm{mg} / \mathrm{L}$, milligrams per liter; $\mathrm{N}$, nitrogen; $<$, less than]

\begin{tabular}{|c|c|c|c|c|c|c|c|c|c|}
\hline \multirow{2}{*}{$\begin{array}{l}\text { Constituents } \\
\text { (units) }\end{array}$} & \multicolumn{3}{|c|}{ Geochemical Group 1} & \multicolumn{3}{|c|}{ Geochemical Group 2} & \multicolumn{3}{|c|}{ Geochemical Group 3} \\
\hline & Minimum & Median & Maximum & Minimum & Median & Maximum & Minimum & Median & Maximum \\
\hline \multicolumn{10}{|c|}{ Physical properties } \\
\hline Specific Conductance $(\mu \mathrm{S} / \mathrm{cm})$ & 114 & 200 & 658 & 95 & 197 & 592 & 114 & 428 & 1,496 \\
\hline Dissolved Oxygen (mg/L) & 1.23 & 7.71 & 9.89 & 1 & 6.78 & 10.24 & 2.67 & 5.68 & 9.06 \\
\hline Bicarbonate (mg/L) & $<0.1$ & 5.00 & 43.80 & $<0.1$ & 2.8 & 12.8 & 4.90 & 16.50 & 147.90 \\
\hline Calcium (mg/L) & 9.157 & 18.39 & 56.85 & 5.06 & 7.50 & 20.25 & 1.21 & 11.11 & 59.53 \\
\hline Chloride $(\mathrm{mg} / \mathrm{L})$ & 5.655 & 14.65 & 54.60 & 9.35 & 29.64 & 136.85 & 12.80 & 89.68 & 430.31 \\
\hline Magnesium (mg/L) & 3.385 & 9.01 & 23.53 & 0.83 & 3.63 & 12.26 & 1.67 & 4.17 & 32.93 \\
\hline Nitrate $(\mathrm{mg} / \mathrm{L}$ as $\mathrm{N})$ & 3.000 & 10.15 & 41.47 & 2.21 & 5.55 & 10.25 & 0.34 & 1.56 & 6.83 \\
\hline Sulfate (mg/L) & 3.928 & 27.30 & 99.30 & 5.73 & 10.71 & 36.59 & 3.50 & 21.03 & 65.69 \\
\hline
\end{tabular}

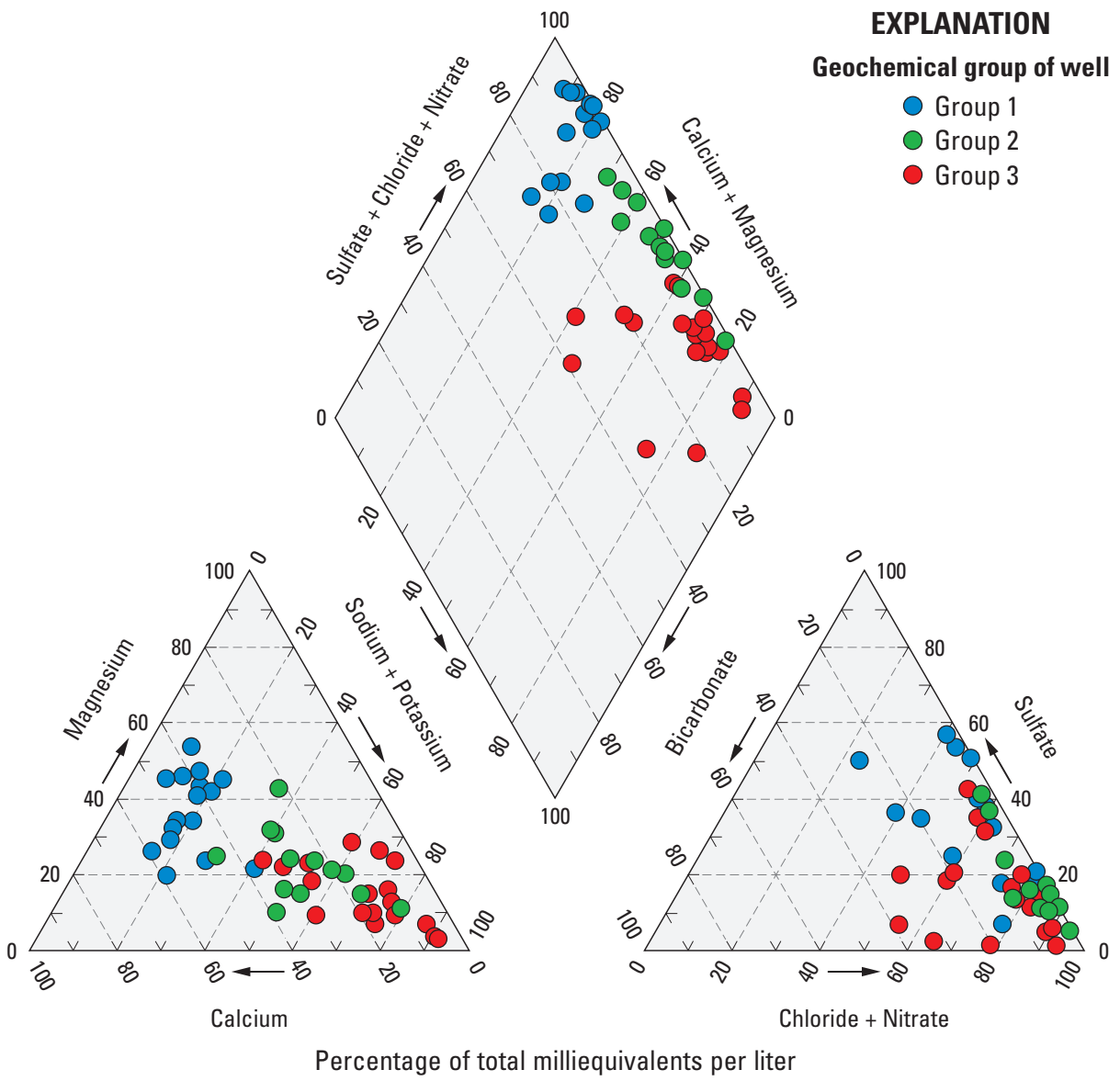

Figure 6. Trilinear diagram of major ions within the surficial aquifer of the Delaware Coastal Plain by geochemical groups. 


\section{Nitrate}

Nitrate is the predominant nutrient found in the surficial aquifer of the Delaware Coastal Plain, with a median concentration of $4.95 \mathrm{mg} / \mathrm{L}$ in samples collected from the 48 wells. In the three groups of wells determined by correlation and cluster analysis, geochemical group 1 had the highest median nitrate concentration at $10.15 \mathrm{mg} / \mathrm{L}$, exceeding the EPA drinking-water standard for public water systems of $10 \mathrm{mg} / \mathrm{L}$ (U.S. Environmental Protection Agency, 2009) (fig. 7A; table 3). Nitrate concentrations in group 1 were different than the nitrate concentrations in group 3 at the $(\mathrm{p}<0.05)$ level of significance. Group 1 also had the highest median values of calcium and magnesium (figs. $7 B$ and $7 C$, table 3 ) and differs from group 2 at the $(p<0.05)$ level of significance. Calcium and magnesium in group 3 were not different than groups 1 or 2 at the $(\mathrm{p}<0.05)$ level of significance. Group 1 had the highest percentage of agricultural land in the
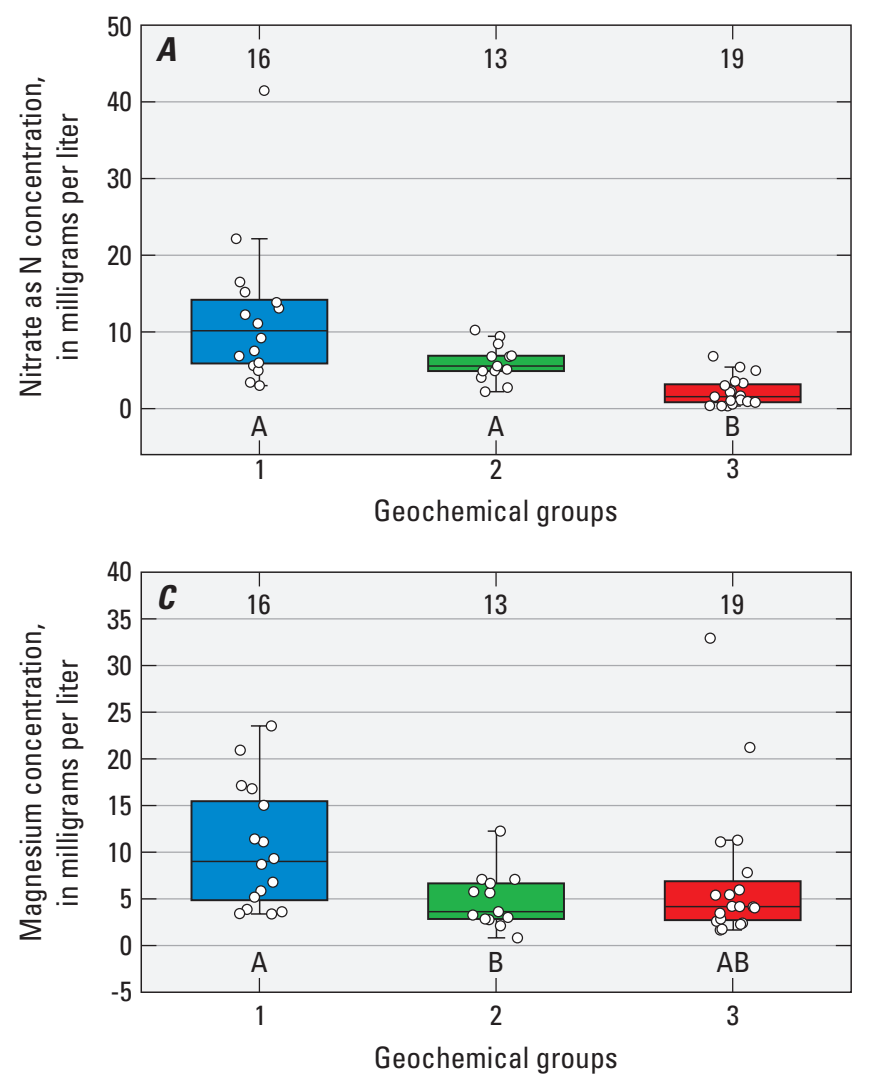

1,640-ft-radius land buffer analysis (fig. $8 A$ ), but was not different from groups 2 or 3 at the $(p<0.05)$ level of significance. Groundwater collected from wells in group 1 exhibited characteristics described as having an agricultural signature (calcium-magnesium-nitrate water type; fig. 6) in previous studies on the Delmarva Peninsula (Böhlke, 2002; Denver, 1989; Hamilton and others, 1993).

Group 3, which had the highest percentage of developed land near the wells (fig. 8B), had the lowest median nitrate concentrations $(1.55 \mathrm{mg} / \mathrm{L}$, table 3$)$. Nitrate concentrations in the surficial aquifer have been shown to be lower in urban and developed areas compared to agricultural areas (Denver and others, 2014). The median concentration of nitrate in group 2 $(5.55 \mathrm{mg} / \mathrm{L})$ is between groups 1 and 3 . The overall geochemical signature of group 2 (fig. 6, table 3 ) appears to be a blend of the group 1 (high nitrate, low chloride) and group 3 (low nitrate, high chloride) end members.

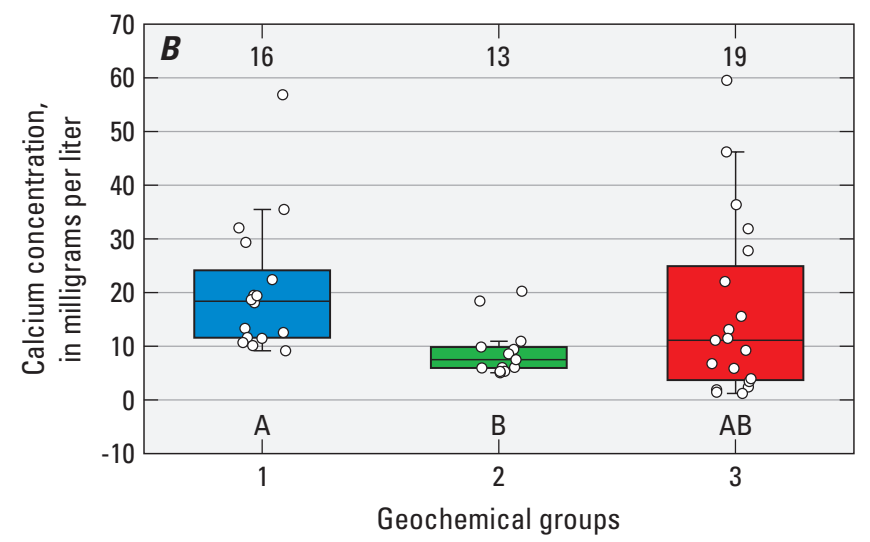

EXPLANATION

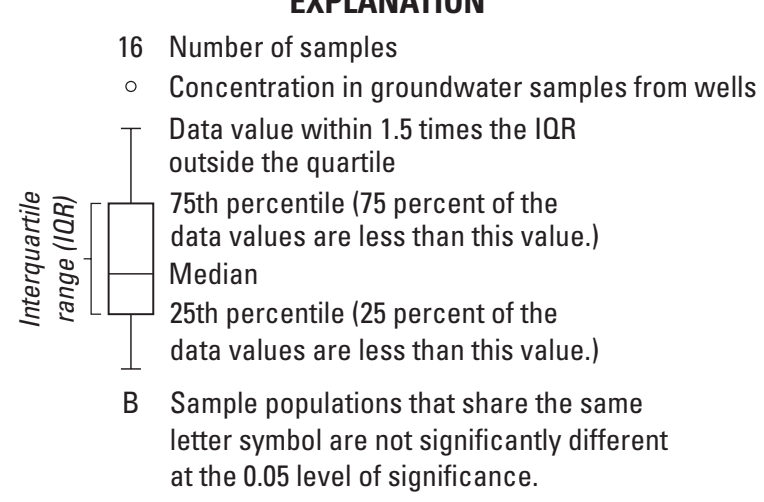

Figure 7. Boxplots of $A$, nitrate, $B$, calcium, and $C$, magnesium concentrations by geochemical groups. 


\section{Chloride}

Chloride concentrations in natural groundwater are typically low (Hem, 1985), but elevated concentrations of sodium and chloride in groundwater are common in the United States (Panno and others, 2006). Common sources of chloride in groundwater are from deicing activities, commercial fertilizer, sewage and animal wastes, landfill leachate, seawater intrusion, and migration of formation brines (Mullaney and others, 2009). In Delaware, likely sources of chloride in groundwater are from deicing, potassium chloride fertilizers, and septic and animal wastes. Seawater intrusion may be a source near the coast, but because all wells in this study are at least several miles from the coast, it is unlikely that it affected the chloride concentrations in shallow groundwater that was sampled. The highest median concentrations of chloride $(89 \mathrm{mg} / \mathrm{L})$ were measured in samples collected from wells in group 3 (table 3, fig. 9A). These differ from chloride concentrations in group 1

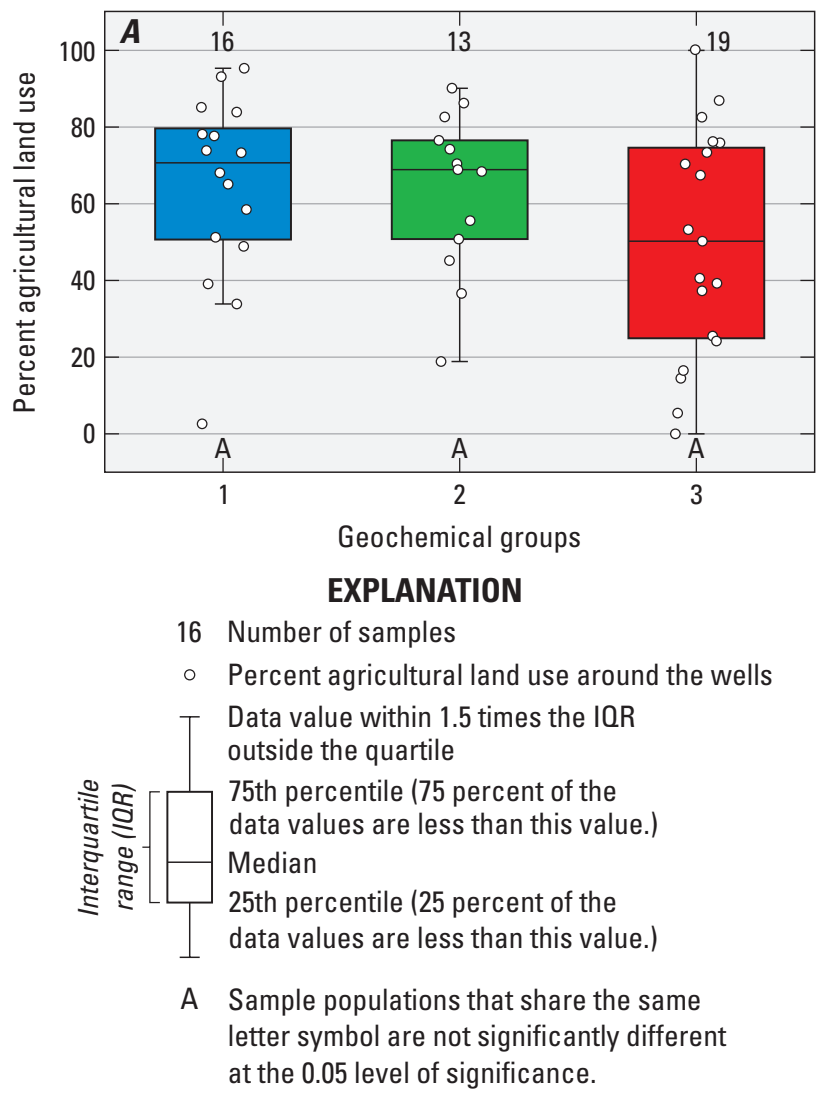

at the $(p<0.05)$ level of significance. The ratio of chloride to bromide, often used to identify potential sources of chloride, was also much higher in group 3 than in groups 1 or 2, with a median value of over 2,000. Ten of the 19 wells in group 3 had chloride to bromide ratios above 2,000 (fig. 9B), typical of chloride with a halite source (Mullaney and others, 2009). Samples from wells in the northern part of the study area showed the highest chloride to bromide ratios and the highest chloride concentrations (fig. 9C). Wells in group 3 also had the highest percentage of developed land use near them (fig. 8B), which may be related to increased chloride from deicing activity. In general, more deicing products are used on roads in urban and suburban areas, and in Delaware, that includes more of the northern part of the Coastal Plain where ice is a greater problem. Although it is difficult to identify the exact sources of chloride, the chloride to bromide ratios in group 3 are significantly different from the chloride to bromide ratios in group 1 (fig. 9B).

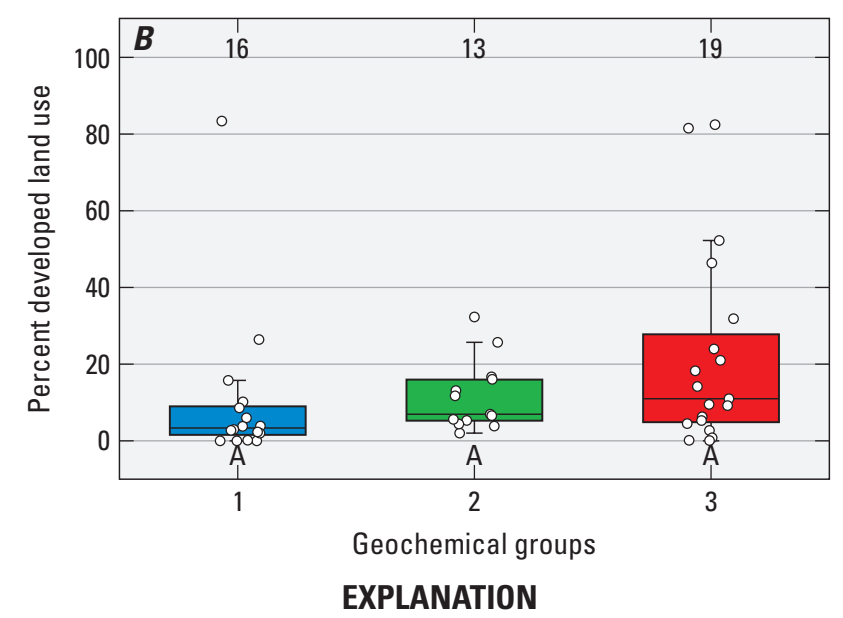

16 Number of samples

- Percent developed land use around the wells

Tata value within 1.5 times the IOR outside the quartile

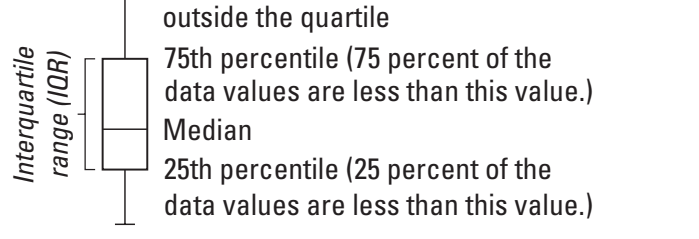

A Sample populations that share the same letter symbol are not significantly different at the 0.05 level of significance.

Figure 8. Boxplots of $A$, agricultural land use, and $B$, developed land use by geochemical groups. 


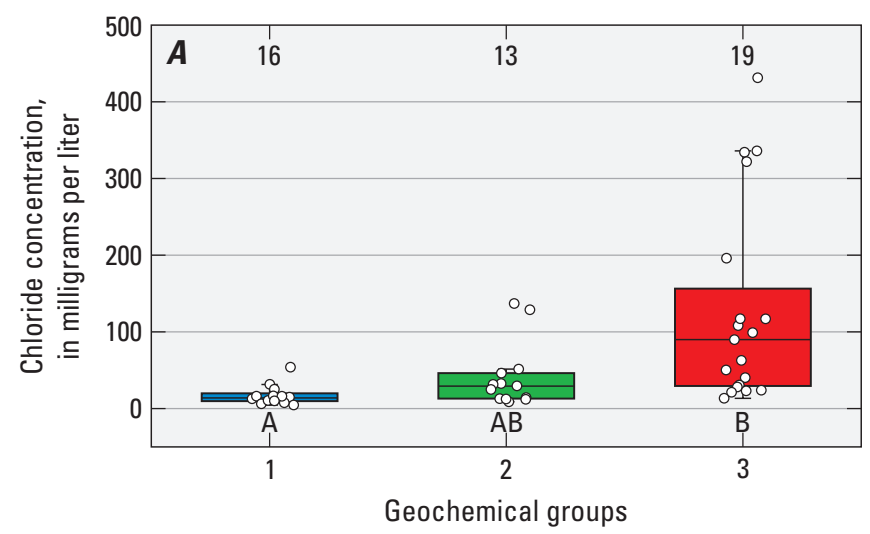

EXPLANATION

16 Number of samples

- Chloride concentration in groundwater samples from wells

T Data value within 1.5 times the IOR outside the quartile

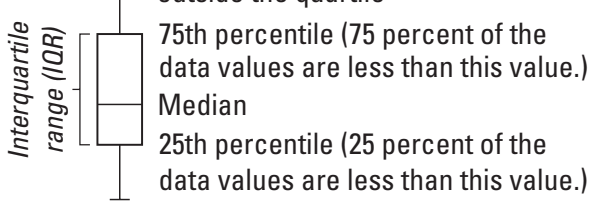

B Sample populations that share the same letter symbol are not significantly different at the 0.05 level of significance.

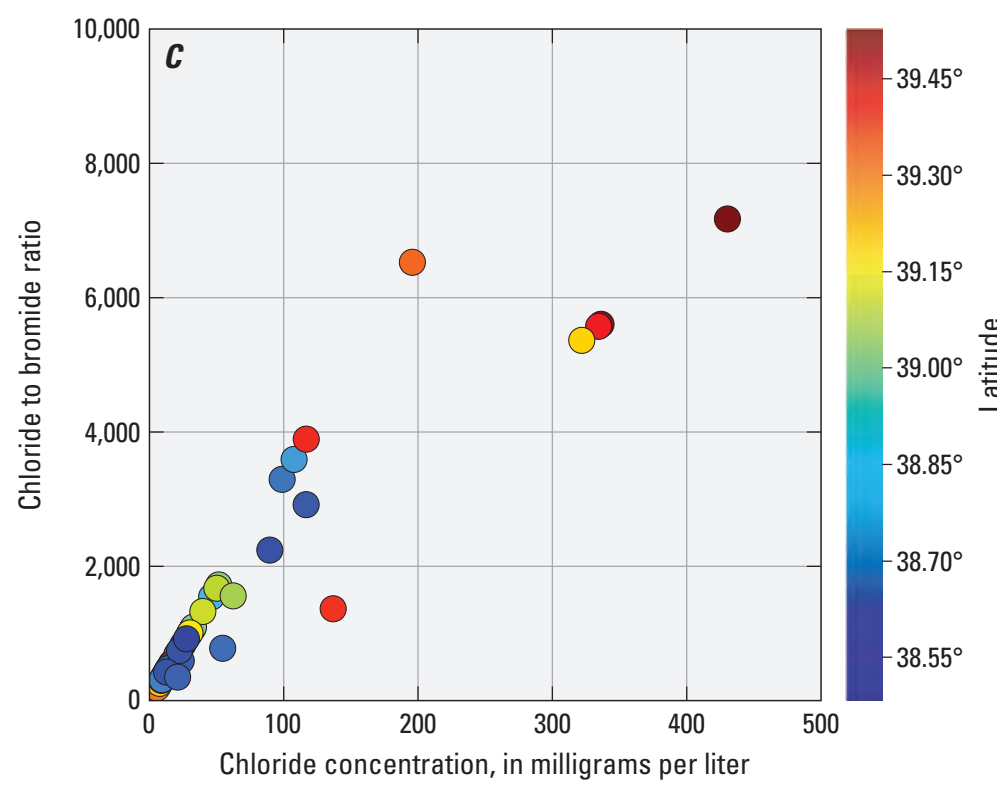

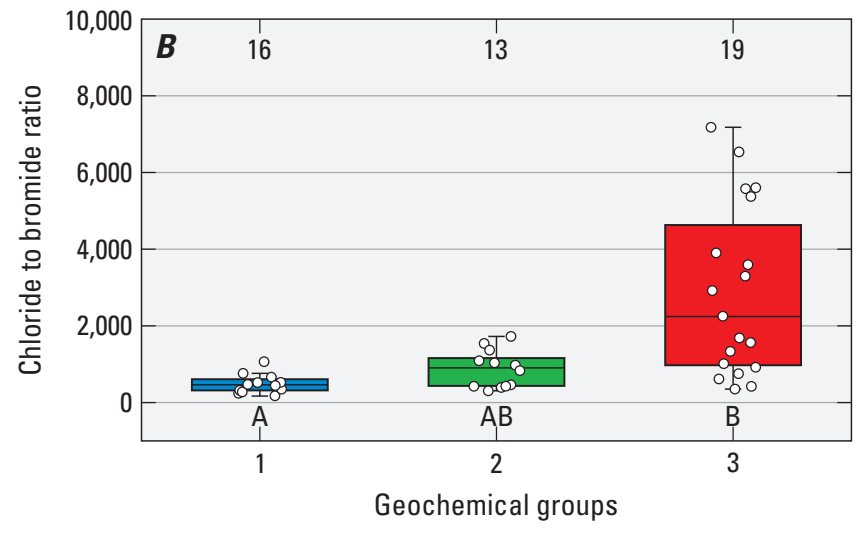

EXPLANATION

16 Number of samples

- Chloride to bromide ratio in groundwater samples from wells

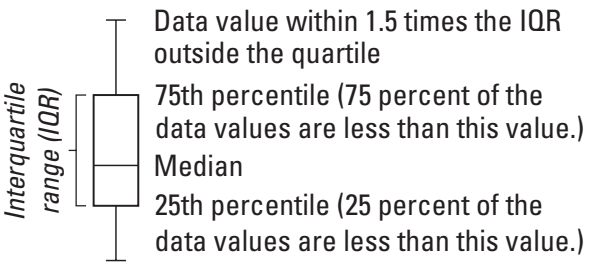

B Sample populations that share the same letter symbol are not significantly different at the 0.05 level of significance.

Figure 9. Boxplots of $A$, chloride, $B$, chloride to bromide ratio by geochemical groups, and $C$, scatter plot of chloride to bromide ratio compared to chloride by latitude. 


\section{Summary and Conclusions}

The U.S. Geological Survey, in cooperation with the Delaware Department of Agriculture designed a network of wells to monitor groundwater quality in the surficial aquifer of the Delaware Coastal Plain. Wells in existing groundwater networks throughout the Delmarva Peninsula were selected to assess water-quality conditions over the entire Delmarva Peninsula and many water-quality parameters, including nitrate. Because of the broad nature of these existing network designs, the number of wells located in settings where nitrate is present was small, limiting the use of statistical methods to determine whether changes in nitrate concentrations are occurring over time. The network designed for this study takes advantage of what was learned about the factors affecting spatial variability in nutrients and targets those settings (shallow wells at the water table, young groundwater [recently recharged], well-drained soils, and oxic groundwater) where changes in nitrate are most likely to be observed. Forty-eight wells were identified from two existing groundwater-monitoring networks in the surficial aquifer of the Delaware Coastal Plain and sampled for water quality in 2014.

The wells sampled in 2014 were grouped based on their similarity in geochemistry using correlation and cluster analysis. These groups were effective in explaining some of the variability within the network, especially for nitrate and chloride concentrations. Although spatial patterns were not evident for nitrate, land-use patterns near wells appear to be a factor in the geochemistry of shallow groundwater. Results of this study showed that the highest median nitrate concentrations are in the group with the highest percentage of agricultural land use and the highest median chloride concentrations are in the group with the highest percentage of developed land use. There appears to be a spatial pattern in chloride concentrations, with higher values in the northern part of the study area that may be related to deicing activities. These groups of wells can be evaluated for trends independently of the entire network with future sampling, which could be useful in identifying where agricultural best management practices (BMPs) are most effective at reducing the leaching of nutrients to shallow groundwater.

The implementation of agricultural BMPs across Delaware over the last several decades has had a goal of reducing the leaching of nitrate into shallow groundwater. In the surficial aquifer of the Delaware Coastal Plain, changes in water quality that may be attributed to agricultural BMPs may only become apparent with repeated monitoring over long periods of time. The results of this study are intended to establish water-quality conditions in 2014 to allow future comparison and evaluate the effectiveness of BMPs on a regional scale.

\section{References Cited}

Ator, S.W., 2008, Natural and human influences on water quality in a shallow regional unconsolidated aquifer, Northern Atlantic Coastal Plain: U.S. Geological Survey Scientific Investigations Report 2008-5190, 21 p., accessed September 15, 2016, at https://pubs.usgs.gov/ $\operatorname{sir} / 2008 / 5190 /$.

Ator, S.W. and Denver, J.M., 2015, Understanding nutrients in the Chesapeake Bay watershed and implications for management and restoration-The Eastern Shore: U.S. Geological Survey Circular 1406, 72 p., accessed April 7, 2017, at http://dx.doi.org/10.3133/cir1406.

Ator, S.W., Denver, J.M., Krantz, D.E., Newell, W.L., and Martucci, S.K., 2005, A surficial hydrogeologic framework for the Mid-Atlantic Coastal Plain: U.S. Geological Survey Professional Paper 1680, 44 p., accessed April 7, 2017, at https://pubs.usgs.gov/pp/1680/report.pdf.

Bachman, L.J. and Wilson, J.M., 1984, The Columbia aquifer of the Eastern Shore of Maryland: Maryland Geological Survey Report of Investigations No. 40, 144 p., accessed April 7, 2017, at http://www.mgs.md.gov/publications/ report_pages/RI_40.html.

Blaier, S.C., and Baxter, S.J., 2000, The occurrence and distribution of several agricultural pesticides in Delaware's shallow ground water: Delaware Geological Survey Report of Investigations No. 61, 23 p., accessed April 7, 2017, at http://www.dgs.udel.edu/publications/ri61-occurrence-and-distribution-several-agricultural-pesticidesdelaware $\% \mathrm{E} 2 \% 80 \% 99$ s-shallow-gro.

Böhlke, J.K., 2002, Groundwater recharge and agricultural contamination: Hydrogeology Journal, v. 10, no. 1, p. 153-179, DOI: 10.1007/s10040-001-0183-3, accessed April 7, 2017, at http://link.springer.com/article/10.1007/ s10040-001-0183-3.

Brakebill, J.W. and Gronberg, J.M., 2017, County-level estimates of nitrogen and phosphorus from commercial fertilizer for the conterminous United States, 1987-2012: U.S. Geological Survey data release, accessed November 15, 2016, at https://doi.org/10.5066/F7H41PKX.

Burow, K.R., Jurgens, B.C., Belitz, Kenneth, and Dubrovsky, N.M., 2012, Assessment of regional change in nitrate concentrations in groundwater in the Central Valley, California, USA, 1950s-2000s: Environmental Earth Sciences, v. 69, no. 8, p. 2,609-2,621, accessed April 7, 2017, at http:// dx.doi.org/10.1007/s12665-012-2082-4. 
Busenberg, Eurybiades, and Plummer, L.N., 2000, Dating young groundwater with sulfur hexafluoride: Natural and anthropogenic sources of sulfur hexafluoride: Water Resources Research, v. 36, no. 10, p. 3,011-3,030, DOI: 10.1029/2000WR900151, accessed April 7, 2017, at http://onlinelibrary.wiley.com/doi/10.1029/2000WR900151/ abstract.

Clune, J.W., and Denver, J.M., 2012, Residence time, chemi$\mathrm{cal}$ and isotopic analysis of nitrate in the groundwater and surface water of a small agricultural watershed in the Coastal Plain, Bucks Branch, Sussex County, Delaware: U.S. Geological Survey Scientific Investigations Report 2012-5235, 15 p., accessed April 7, 2017, at https://pubs. usgs.gov/sir/2012/5235/.

Debrewer, L.M., Ator, S.W., and Denver, J.M., 2007, Factors affecting spatial and temporal variability in nutrient and pesticide concentrations in the surficial aquifer on the Delmarva Peninsula: U.S. Geological Survey Scientific Investigations Report 2005-5257, 44 p., accessed April 11, 2017, at https://pubs.usgs.gov/sir/2005/5257/.

Debrewer, L.M., Ator, S.W., and Denver, J.M., 2008, Temporal trends in nitrate and selected pesticides in MidAtlantic ground water: Journal of Environmental Quality, v. 37, no. 5_Supplement, p. S-296-S-308, DOI: 10.2134. jeq2007.0664, accessed October 4, 2016, at https:// dl.sciencesocieties.org/publications/jeq/abstracts/37/5_ Supplement/S-296.

Delaware Code Title 3, §2247(a), Nutrient Management Plans, accessed April 11, 2017, at http://delcode.delaware.gov/sessionlaws/ga140/chp060.shtml.

Delaware Department of Agriculture, 2012, Agricultural Compliance Laboratory sample database, p. 48, accessed October 4, 2016, at https://www.nass.usda.gov/Statistics_ by_State/Delaware/Publications/Annual_Statistical_ Bulletin/2011/DE\%20Ag\%202012.pdf.

Delaware Department of Agriculture, 2015, Delaware Nutrient Management Commission Annual Report, 17 p., accessed on October 4, 2016, at http://dda.delaware.gov/pdfs/nutrients/2015_NMC_Report.pdf.

Delaware Department of Natural Resources and Environmental Control, 2015, State of Delaware 2014 Combined Watershed Assessment Report (305(b)) and Determination for the Clean Water Act section 303(d) List of Waters Needing TMDLs, accessed October 27, 2016, at http://www.dnrec.delaware.gov/swc/wa/Documents/WAS/ dave $\% 27 \mathrm{~s} \% 20$ docs $/ 2014 \% 20$ Delaware $\% 20$ Integrated $\% 20$ $305 \% 28 \mathrm{~b} \% 29-303 \% 28 \mathrm{~d} \% 29 \% 20$ Final.pdf.
Denver, J.M., 1989, Effects of agricultural practices and septic-system effluent on the quality of water in the unconfined aquifer in parts of eastern Sussex County, Delaware: Delaware Geological Survey Report of Investigations No. 45, 66 p., accessed April 11, 2017, at http://www.dgs. udel.edu/publications/ri45-effects-agricultural-practicesand-septic-system-effluent-quality-water-unconfined.

Denver, J.M., Ator, S.W., Debrewer, L.M., Ferrari, M.J., Barbaro, J.R., Hancock, T.C., Brayton, M.J., and Nardi, M.R., 2004, Water quality in the Delmarva Peninsula, Delaware, Maryland, and Virginia, 1999-2001: U.S. Geological Survey Circular 1228, 40 p., accessed October 4, 2016, at http://pubs.water.usgs.gov/circ1228/.

Denver, J.M., Ator, S.W., Fischer, J.M, Harned, D.C., Schubert, Christopher, and Szabo, Zoltan, 2014, The quality of our Nation's waters-Water quality in the Northern Atlantic Coastal Plain surficial aquifer system, Delaware, Maryland, New Jersey, New York, North Carolina, and Virginia, 1988-2009: U.S. Geological Survey Circular 1353, 88 p., accessed April 11, 2017, at https://dx.doi. org/10.3133/cir1353.

Denver, J.M., and Nardi, M.R., 2016, Thickness of the surficial aquifer, Delmarva Peninsula, Maryland and Delaware: U.S. Geological Survey data release, accessed April 11, 2017, at http://dx.doi.org/10.5066/F7610XFT.

Fishman, M.J., ed., 1993, Methods of analysis by the U.S. Geological Survey National Water Quality LaboratoryDetermination of inorganic and organic constituents in water and fluvial sediments: U.S. Geological Survey OpenFile Report 93-125, 217 p., accessed April 11, 2017, at https://nwql.usgs.gov/rpt.shtml?OFR-93-125.

Frans, L.M., and Helsel, D.R., 2005, Evaluating regional trends in ground-water nitrate concentrations of the Columbia Basin Ground Water Management Area, Washington: U.S. Geological Survey Scientific Investigations Report 2005-5078, 7 p., accessed April 11, 2017, at https://pubs.usgs.gov/sir/2005/5078/.

Giraudoux, Patrick, 2017, pgirmess: Data Analysis in Ecology, R package version 1.6.5., accessed October 11, 2016, at http://CRAN.R-project.org/package=pgirmess.

Gronberg, J.M., and Arnold, T.L., 2017, County-level estimates of nitrogen and phosphorus from animal manure for the conterminous United States, 2007 and 2012: U.S. Geological Survey Open-File Report 2017-1021, 6 p., accessed November 15, 2016, https://doi.org/10.3133/ ofr20171021. 
Haering, K.C., and Evanylo, G.K., eds., 2006, The MidAtlantic Nutrient Management Handbook: 252 p., accessed September 15, 2016, at https://extension.umd.edu/sites/ extension.umd.edu/files/_docs/programs/anmp/MANMH_ complete.pdf.

Hamilton, P.A., Denver, J.M., Phillips, P.J., and Shedlock, R.J., 1993, Water-quality assessment of the Delmarva Peninsula, Delaware, Maryland and Virginia-Effects of agricultural activities on, and the distribution of, nitrate and other inorganic constituents in the surficial aquifer: U.S. Geological Survey Open-File Report 93-40, 87 p., accessed April 12, 2017, at https://pubs.usgs.gov/of/1993/0040/report.pdf.

Hansen, Birgitte, Thorling, Lærke, Dalgaard, Tommy, and Erlandsen, Mogens, 2011, Trend reversal of nitrate in Danish groundwater - a reflection of agricultural practices and nitrogen surpluses since 1950: Environmental Science \& Technology, v. 45, no. 1, p. 288-234., DOI: 10.1021/ es102334u, accessed April 12, 2017, at http://pubs.acs.org/ doi/abs/10.1021/es102334u.

Helsel, D.R., and Hirsch, R.M., 2002, Statistical methods in water resources: Techniques of Water-Resources Investigations, book 4, chap. A3, 522 p., accessed April 12, 2017, at https://pubs.usgs.gov/twri/twri4a3/.

Hem, J.D., 1985, Study and interpretation of the chemical characteristics of natural water: U.S. Geological Survey Water Supply Paper 2254, 263 p., accessed April 12, 2017, at https://pubs.usgs.gov/wsp/wsp2254/.

Jordan, R.R., 1964, Columbia (Pleistocene) sediments of Delaware: Delaware Geological Survey Bulletin No. 12, 69 p., accessed April 12, 2017, at http://www.dgs.udel.edu/ publications/b12-columbia-pleistocene-sediments-delaware.

Koterba, M.T., Shedlock, R.J., Bachman, L.J., and Phillips, P.J., 1990, Regional and targeted groundwater quality networks in the Delmarva Peninsula, in Nash, R.G., and Leslie, A.R., eds., Groundwater residue sampling design: Washington, D.C., American Chemical Society Symposium Series, no. 465, chap. 6, p. 110-138.

Koterba, M.T., Wilde, F.D., and Lapham, W.W., 1995, Ground-water data-collection protocols and procedures for the National Water-Quality Assessment ProgramCollection and documentation of water-quality samples and related data: U.S. Geological Survey Open-File Report 95-399, 114 p., accessed April 14, 2017, at https://pubs. er.usgs.gov/publication/ofr95399.
Leahy, P.P., and Martin, Mary, 1993, Geohydrology and simulation of ground-water flow in the Northern Atlantic Coastal Plain aquifer system: U.S. Geological Survey Professional Paper 1404-K, 81 p., 22 pls., accessed October 4, 2016, at http://pubs.er.usgs.gov/publication/pp1404K.

Maiss, Manfred, and Brenninkmeijer, C.A.M., 1998, Atmospheric $\mathrm{SF}_{6}$ : Trends, sources, and prospects: Environmental Science \& Technology, v. 32, no. 20, p. 3,077-3,086, DOI: 10.1021/es9802807, accessed April 14, 2017, at http://pubs.acs.org/doi/abs/10.1021/es9802807.

Maizel, M.S., Muehlbach, George, Baynham, Paul, Zoerkler, Jennifer, Monds, Darlene, Iivari, Tom, Welle, Paul, Robbin, Jonathan, and Wiles, Janice, 1997, The potential for nutrient loadings from septic systems to ground and surface water resources and the Chesapeake Bay: U.S. Environmental Protection Agency EPA 903-R-97-006, Report CBP/TRS 166/97, 285 p., accessed November 15, 2016, at http://nepis. epa.gov/Exe/ZyPURL.cgi?Dockey=P1001WW6.txt.

Masterson, J.P., Pope, J.P., Fienen, M.N., Monti, Jack, Jr., Nardi, M.R., and Finkelstein, J.S., 2016, Assessment of groundwater availability in the Northern Atlantic Coastal Plain aquifer system from Long Island, New York, to North Carolina: U.S. Geological Survey Professional Paper 1829, 76 p., accessed April 14, 2017, at http://dx.doi.org/10.3133/ pp1829.

McMahon, P.B., and Chapelle, F.H., 2008, Redox processes and water quality of selected principal aquifer systems: Ground Water, v. 46, no. 2, p. 259-271, accessed April 14, 2017, at http://dx.doi.org/10.1111/j.17456584.2007.00385.x.

Mixon, R.B., 1985, Stratigraphic and geomorphic framework of uppermost Cenozoic deposits in the southern Delmarva Peninsula, Virginia and Maryland: U.S. Geological Survey Professional Paper 1067-G, 53 p., 2 pls., accessed April 14, 2017, at https://pubs.er.usgs.gov/publication/pp1067G.

Mullaney, J.R., Lorenz, D.L., and Arntson, A.D., 2009, Chloride in groundwater and surface water in areas underlain by the glacial aquifer system, northern United States: U.S. Geological Survey Scientific Investigations Report 2009-5086, 41 p., accessed April 14, 2017, at https://pubs. usgs.gov/sir/2009/5086/.

National Atmospheric Deposition Program, 2015, Total deposition maps, ver. 2016.01, accessed April 14, 2017, at http://nadp.sws.uiuc.edu/committees/tdep/tdepmaps. 
Nolan, B.T., Hitt, K.J., and Ruddy, B.C., 2002, Probability of nitrate contamination of recently recharged groundwaters in the conterminous United States: Environmental Science \& Technology, v. 36 , no. 10 , p. $2,138-2,145$, DOI: $10.1021 /$ es0113854, accessed April 17, 2017, at http://pubs.acs.org/ doi/abs/10.1021/es0113854.

Owens, J.P. and Denny, C.S., 1979, Upper Cenozoic deposits of the central Delmarva Peninsula, Maryland and Delaware: U.S. Geological Survey Professional Paper 1067-A, 28 p., accessed April 17, 2017, at https://pubs.er.usgs.gov/publication/pp1067A.

Panno, S.V., Hackley, K.C., Hwang, H.H., Greenberg, S.E., Krapac, I.G., Landsberger, S., and O'Kelly, D.J., 2006, Characterization and identification of $\mathrm{Na}-\mathrm{Cl}$ sources in ground water: Ground Water, v. 44, no. 2, p. 176-187, DOI: 10.1111/j.1745-6584.2005.00127.x, accessed April 17, 2017, at http://onlinelibrary.wiley.com/doi/10.1111/j.17456584.2005.00127.x/full.

Pedregosa, Fabian, Varoquaux, Gaël, Gramfort, Alexandre, Michel, Vincent, Thirion, Bertrand, Grisel, Olivier, Blondel, Mathieu, Prettenhofer, Peter, Weiss, Ron, Dubourg, Vincent, Vanderplas, Jake, Passos, Alexandre, Cournapeau, David, Brucher, Matthieu, Perrot, Matthieu, and Duchesnay, Édouard, 2011, Scikit-learn: Machine learning in Python: Journal of Machine Learning Research, v. 12, p. 2,8252,830, accessed April 18, 2017, at http://www.jmlr.org/ papers/volume12/pedregosa11a/pedregosa11a.pdf.

Plaster, E.J., 1997, Soil science and management (3d ed.): Albany, N.Y., Delmar Publishers, 402 p.

Ramsey, K.W., and Groot, J.J., 1997, Geology of the Milford and Mispillion River Quadrangles, Delaware: Delaware Geological Survey Report of Investigations No. 55, 45 p., accessed April 18, 2017, at http://www.dgs.udel.edu/ publications/ri55-geology-milford-and-mispillion-riverquadrangles.

Rounds, S.A., 2006, Alkalinity and acid neutralizing capacity (ver. 3.0): U.S. Geological Survey Techniques of Water-

Resources Investigations, book 9, chap. A6., sec. 6.6, July 2006, accessed August 12, 2016, at http://pubs.water.usgs. gov/twri9A6/.

Rudolph, D.L., 2015, Groundwater quality within the agricultural landscape: Assessing the performance of nutrient BMPs: Groundwater Monitoring \& Remediation, v. 35, no.1, Winter 2015, p. 21-22, DOI: 10.1111/gwmr.12106, accessed April 18, 2017, at http://onlinelibrary.wiley.com/ doi/10.1111/gwmr.12106/full.
Sanford, W.E., Pope, J.P., Selnick, D.L., and Stumvoll, R.F., 2012, Simulation of groundwater flow in the shallow aquifer system of the Delmarva Peninsula, Maryland and Delaware: U.S. Geological Survey Open-File Report 2012-1140, 58 p., available only at https://pubs.usgs.gov/ of/2012/1140/.

Shedlock, R.J., Hamilton, P.A., Denver, J.M., and Phillips, P.J., 1993, Multiscale approach to regional ground-waterquality assessment of the Delmarva Peninsula, in Alley, W.M., ed., Regional ground-water quality: New York, Van Nostrand Reinhold, p. 563-587.

Shober, A.L., 2015, Nitrogen cycling in agriculture: University of Delaware Cooperative Extension Fact Sheet, 4 p., accessed April 18, 2017, at http://extension.udel.edu/factsheets/nitrogen-cycling-in-agriculture/.

Soil Survey Staff, 2016, The Gridded Soil Survey Geographic (gSSURGO) Database for Delaware: United States Department of Agriculture, Natural Resources Conservation Service, accessed April 18, 2017, at https:// www.nrcs.usda.gov/wps/portal/nrcs/surveylist/soils/survey/ state/?stateId=DE.

State of Delaware, 2007, Delaware Geographic Data Committee, Land use and Soils Data, http://firstmap.gis. delaware.gov/arcgis/rest/services/PlanningCadastre/DE_ LULC_2007_Revised/FeatureServer/0.

U.S. Department of Agriculture, 2012, Census of Agriculture 2012, National Agricultural Statistics Survey, 2012.

U.S. Department of Agriculture, Natural Resources Conservation Service, Delaware Conservation Practice Standard Cover Crop Code 340-3, September 2014, accessed April 17, 2017, at https://www.nrcs.usda.gov/ Internet/FSE_DOCUMENTS/stelprdb1263176.pdf.

U.S. Environmental Protection Agency, 2009, National Primary Drinking Water Regulations, U.S. Environmental Protection Agency Report EPA 816-F-09-004, 6 p., accessed October 11, 2016, at https://www.epa.gov/sites/production/ files/2016-06/documents/npwdr_complete_table.pdf.

U.S. Geological Survey, variously dated, National field manual for the collection of water-quality data: U.S. Geological Survey Techniques of Water-Resources Investigations, book 9, chaps. A1-A10, accessed April 18, 2017, at https://water.usgs.gov/owq/FieldManual/.

Ward, J.H., Jr., 1963, Hierarchical grouping to optimize an objective function: Journal of the American Statistical Association, v. 58, no. 301, p. 236-244, accessed April 18, 2017, at http://www.tandfonline.com/doi/abs/10.1080/0162 1459.1963.10500845. 
Prepared by USGS West Trenton Publishing Service Center. Edited by Valerie M. Gaine.

Graphics and layout by Timothy W. Auer.

For additional information, contact:

Director, MD-DE-DC Water Science Center

U.S. Geological Survey

5522 Research Park Drive

Baltimore, MD 21228

or visit our website at:

http://md.water.usgs.gov 


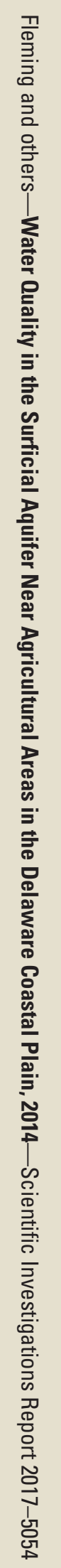

